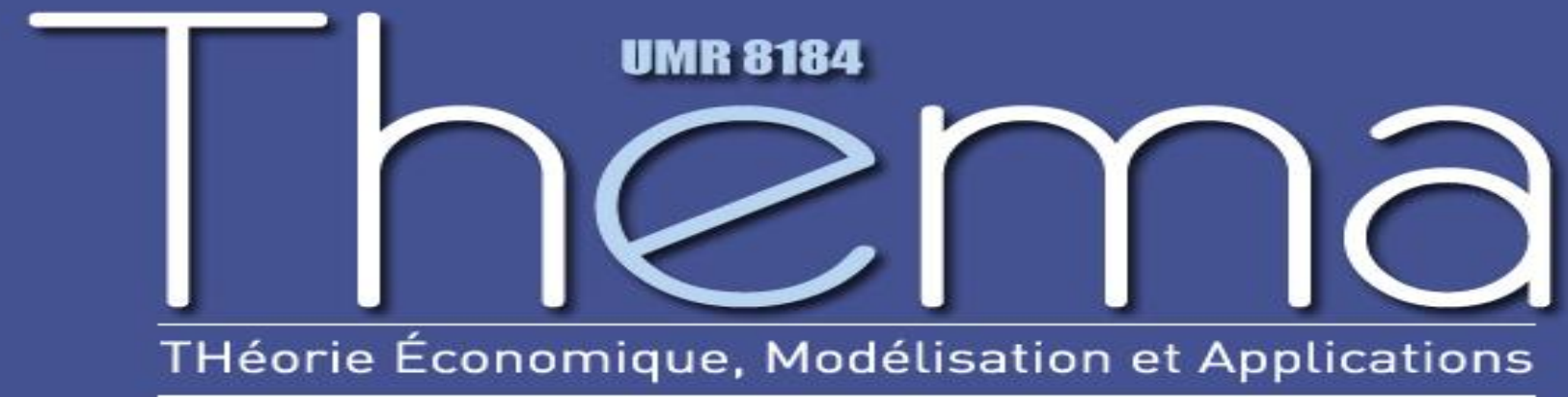

Thema Working Paper $\mathrm{n}^{\circ}$ 2012-33

Université de Cergy Pontoise, France

Rent Building, Rent Sharing A Panel CountryIndustry Empirical Analysis

Paul Maarek

Philippe Askenazy

Gilbert Cette

March, 2012 


\title{
RENT BUILDING, RENT SHARING A PANEL COUNTRY-INDUSTRY EMPIRICAL ANALYSIS
}

\author{
Philippe Askenazy ${ }^{\mathrm{a}}$, Gilbert Cette ${ }^{\mathrm{b}}$ and Paul Maarek ${ }^{\mathrm{c}}$
}

March 2012

\begin{abstract}
This paper aims to clarify the role of market regulations in rent creation and rent sharing. For each country-industry-year observation, the rent size (RS), measured by the value added price relative to the GDP price, is assumed to depend solely on direct anti-competitive regulations (ACR) on services and goods. The second step explains the rent sharing process by using the impact of our RS measure on the capital share. ACR on the good market increases rent size. RS increases the capital share but the magnitude highly depends on the bargaining power of the two alternative beneficiaries: workers and upstream industries.
\end{abstract}

Keywords: Rents, capital share, prices, market regulations, output gap, unemployment JEL Classification: E25, J20

a: Paris School of Economic-CNRS, Cepremap, IZA and Banque de France, askenazy@pse.ens.fr

b: Banque de France and Université de la Méditerranée (DEFI), gilbert.cette@ banque-france.fr

c: Banque de France and Université de Cergy-Pontoise (THEMA), paul.maarek@u-cergy.fr

The authors would like to thank seminar participants at the Banque de France, especially David Spector, for their stimulating remarks and suggestions. The views expressed in this paper are those of the authors and do not necessarily reflect the views of the institutions they belong to. 


\section{INTRODUCTION}

In the last two decades, a considerable economic literature has been devoted to the determinants of rent creation and to the mechanisms of rent sharing. Through panel estimates using OECD country-industry data, our empirical analysis aims to clarify these mechanisms, and the impact of market regulations on them. These issues are important for the dynamics of inequalities or for growth analysis: creation and appropriation of rents are among the main motivations for investment, whether physical or intangible, such as R\&D and know-how (for a survey, see Aghion and Howitt, 2010), and also determine the overall level of wages across industries or countries.

Among the numerous papers devoted to this issue, we draw on a few that are particularly related to the approach developed in this analysis. In their theoretical modelling, Blanchard and Giavazzi (2003), and Spector (2004), assume: i) that rents stem from anti-competitive regulations on goods and services industries, and ii) that the sharing process of rents between labour and margins depends on the bargaining power of labour, which in turn is linked to labour market regulation. In these approaches, the share of labour in value added increases with labour bargaining power. Anti-competitive regulations on goods and services industries increase the size of the rents to share and, for a given labour bargaining power, increase real wages as well; however, they have an ambiguous impact on the value added labour or capital shares. In his empirical paper on 600 individual UK firms, Van Reenen (1996) assumes that rents are created by innovations -here's innovation data coming from an original specific survey- these rents being shared between labour and capital depending on labour bargaining power. Here also, the share of labour in value added is shown to increase with labour bargaining power but innovations have an ambiguous impact on it. In their theoretical and empirical cross-country analysis on some network industries, Azmat, Manning and Van Reenen (2011) look at the impact of services and goods market regulations on the labour share. They measure services and goods market regulation using two indicators: public ownership and barriers to entry, whereby they show that the labour share increases with the first indicator (which in fact captures labour bargaining power) and decreases with the second. Recently, Young and Zuleta (2011) proved the advantage of using panel industry-level data in the US case and show that union density (membership or coverage rates) is correlated with labour's share and this correlation increases in the elasticity of substitution between labour and capital. 
Overall, it appears in the literature that the impact of services and goods market regulations appears to be positive on rent creation and real wages, but is more ambiguous on labour and capital sharing of value added. On the other hand, labour market regulations have no significant impact on rent creation but a positive one on real wages and on the labour share.

Here, we use a country-industry panel database. More precisely, the database combines data on 18 industries in 17 OECD countries over the period 1988 to 2007, constituted from the STAN database and the regulation indicators both compiled by the OECD. After accounting for missing data and eliminating spurious observations, we arrive at a quite large dataset of 4,136 observations.

The empirical analysis takes place in two steps. The first explains the rent creation process. For each country-industry-year and observation, the size of rents is measured by the value added price relative to the GDP price. In the estimated relation, the size of rents is assumed to depend solely on direct anti-competitive regulations on services and goods. Several anticompetitive indicators are then tried intern: import taxes, FDI restrictions and barriers to entry. Because of the lack of information at cross country-industry level, innovation has not been directly taken into account to explain the rent size. We may expect that, as competitive pressure decreases with anti-competitive regulations, innovation is also affected by these anticompetitive regulations. It means that our results will indicate the impact on the rent sizes both of anti-competitive regulations and partly indirectly of innovation. More specifically, an increase (decrease) in regulations increases (decreases) rents directly but affects them indirectly impaired incentives to innovate. Then, estimates of the impact of regulations on rent size may be downward-biased and potential impacts estimated in the paper should be interpreted as a lower bound. Our results indicate that the first direct positive effect dominates the second negative indirect one.

The second step explains the rent sharing process. Three destinations of the rents are distinguished for each country-industry-year observation: upstream industries, capital and labour. The first is an original contribution of our study and requires further explanation.

Most empirical studies on the competition-value added sharing process focus on competitive conditions within each industry. But rents should also be reduced by lack of competition in 
industries that sell intermediate inputs that are necessary for production. If there is market power in these upstream industries, firms in downstream industries face higher input prices that mechanically seize their rents. These intuitive mechanisms are described for example by Bourles et al. (2010), among others. In the spirit of this study, we use our relative price variable to measure rents in each industry. We measure the importance of this lack of competition in input-providing industries (henceforth called "upstream" industries) for each industry (henceforth "downstream" industries) by means of input-output relationships. ${ }^{1}$

The relation estimated in the second step explains the capital share in value added by several factors: i) the size of the rents (measured as in the first step), ii) the indirect upstream size of the rent (measured as in the first step) on the services and goods market, iii) labour market anti-competitive regulation, with a negative impact expected, iv) the interactions between the size of rents and labour market regulation, with a negative impact expected, and the unemployment rate with a positive impact expected, v) the position of the country overall or more specifically of the country-industry within the business cycle, with a negative impact for the first and a positive one for the second.

Compared to the existing literature, our approach displays several original features. First, we decompose the two steps: rent building and rent sharing. Second, we distinguish for each country-industry between three destinations for rents: upstream industries, capital and labour. Third, the analysis is conducted at the cross-country-industry data level, giving a broad observation panel which allows us to estimate more complex relations than at a country data level. Thanks to this, the specific impact of some variables can be tested.

The main results of the analysis are as follows. Regarding the rent creation step, the estimates suggest that direct anti-competitive regulations strongly affect the determination of rent size. Concerning the rent sharing step, it appears that the capital share in value added i) increases with rent size, decreases with anti-competitive regulations in upstream sectors and increases with the industry specific output gap; ii) decreases with the national output gap, increases with the national employment rate and decreases with employment protection regulation; iii) increases with the interaction of rent size and the unemployment rate and decreases with the interaction of rent size and employment protection regulations. These results confirm the

Such upstream anticompetitive indicators were used in previous OECD papers, for example Conway et al. (2006) and Arnold et al. (2011). 
existence of three destinations for rents (labour remuneration, capital remuneration and upstream industries) and the fact that the importance of each destination depends on the market power of the recipient concerned. The relations between the value added capital share and the business cycle position are intuitive: an increase in demand pressure increases the market power of a producer but, at the same time, an increase in demand pressure elsewhere but in a specific industry decreases the market power of this industry. All these results seem robust to a variety of sensitivity checks.

The paper is organised as follows. The next section presents the empirical strategy of the study. Section 3 presents the data. The results of the estimates are presented in section 4 . Section 5 includes various robustness checks. A final section concludes.

\section{EMPIRICAL STRATEGY}

In this section, we present the empirical methodology adopted in this paper in order to identify the process of rent creation and rent sharing at the industry/country level.

We proceed in two steps, in the spirit of Van Reenen (1996). We first identify the creation of rent induced by lack of competition. We then study the sharing of these rents. We argue that rents do not necessarily translate fully into profits for the firm but can be captured by other agents. Workers through wage bargaining or input providers -which may themselves be operating in a non-competitive environment- setting higher input price can capture part of these rents.

We first focus on rent creation. This step is devoted to the empirical analysis of the impact of direct anti-competitive regulations on rent size. Our approach is in fact related to the theoretical modelling proposed for example by Blanchard and Giavazzi (2003) and Spector (2004), among others, who assume that rents are determined by anti-competitive regulations. We formally estimate the following relation:

$$
R S_{c s t}=\alpha_{0} . D A C R_{c s t-1}+\sum_{i}\left(\alpha_{i} \cdot F E_{i}\right)+\varepsilon_{c s t}
$$


Where $R S_{c s t}$ and $D A C R_{c s t-1}$ correspond to the rent size for country $c$, the industry $s$ at time $t$ and the anti-competitive regulation indicator for country $c$, the industry $s$ at time $t$ lrespectively. $F E_{i}$ corresponds to a particular fixed-effect $i$ which can be related to the country, the industry and the time dimensions, and $\varepsilon_{c s t}$ is a three-dimensional white noise. A lag of one year is introduced for DACR to take into account some delays in the impact of anticompetitive regulations on rent size and to avoid some simultaneity and endogeneity problems. The coefficient $\alpha_{0}$ is expected to be positive $\left(\alpha_{0}>0\right)$.

We then focus on rent capture. The main idea is that rents do not necessarily translate into higher profits, depending on which agent captures the rent: workers through wage bargaining (a variable we relate to bargaining power) or input providers to downstream industries through setting higher input prices if they benefit from anti-competitive regulations (a variable we relate to indirect prices). We use capital share as a dependent variable to highlight the result from the rent sharing process between these three different agents, namely: upstream industries, downstream industries and workers. Rents can translate into capital share (CS) depending on the ability of firm stakeholders to capture the rent generated from regulation. We formally estimate the following relation:

$$
C S_{c s t}=\beta_{1} \cdot R S_{c s t}+\Sigma_{v}\left(\beta_{v} \cdot X_{v, c s t}\right)+\Sigma_{j}\left(\beta_{j .} X_{j, c s t} \times R S_{c s t}\right)+\sum \beta_{k .} Z_{k, c s t}+\Sigma_{i}\left(\alpha_{i} \cdot F E_{i}\right)+\mu_{c s t}
$$

where $X$ is a set of explanatory variables for rent capture by different agents and $Z$ a set of control variables. We also introduce interaction terms between our explanatory variables for rent capture and the size of rent, reflecting the fact that the size of rent translates into a higher capital share depending on ability of other agents to capture part of this rent. The mean effect of rent size on the capital share ( $\beta_{1}$ if $R S$ is the only regressor to be included in regression) is ambiguous and we do not expect any particular sign. For instance, if the bargaining power of workers is strong enough to capture the entirety of rents through higher wages, rents unambiguously increase the labour share and decrease the capital share. $\mu_{c s t}$ is a threedimensional white noise.

Through the fixed-effects $F E_{i}$, estimates are carried out in a within dimension, within from countryxindustry and industryxtime dimensions and also from a countryxtime dimension. For some second step estimates (rent capture), countryxtime fixed-effects are dropped. Indeed, some explanatory variables have no industry dimension (see below). 
We now detail the choice of variable we include in the regression and present some descriptive statistics.

\section{DATA}

In order to investigate empirically the impact of regulations on rent creations and the determinants of rent capture, we need $i$ ) indicators for rent formation and the distribution of these rents, $\mathrm{ii}$ ) explanatory variables for these two distinct mechanisms. Merging different sources, we were able to assemble a cleaned unbalanced panel of 4,136 observations for 17 countries $^{2}$ and 18 industries ${ }^{3}$ over the 1988-2007 period. For all countries, series start in 1988 with reliable data. A notable exception is for countries from the former Communist Bloc whose capital share after 1989 exhibits abnormal fluctuations. For those countries we choose to start the series in $1995 .^{4}$ As a robustness check we run regressions without those countries and starting series since the beginning data are available. Results remain unaffected (not reported in the paper).

\subsection{Dependent variables}

\subsubsection{First step: rent creation}

There are many measures of rent in the literature. Many authors have focused on mark-up, profit per head, Tobin's Q, or the profit share (see Van Reenen, 1996 for instance). Nevertheless, these measures do not take into account an important dimension of rent which we focus on in this paper: Rents may be captured by workers or any other agent involved in

2 Austria, Belgium, Czech Republic, Denmark, Spain, Finland, France, Germany, Hungary, Italy, Japan, Korea, Netherlands, Norway, Sweden, United Kingdom and United States of America.

3 Food products, beverages and tobacco (15t16); Textiles, textile products, leather and footwear (17t19); Wood and products of wood and cork (20); Pulp, paper, paper products, printing and publishing (21t22); Chemical, rubber, plastics and fuel products (23t25); Other non-metallic mineral products (26); Basic metals and fabricated metal products (27t28); Machinery, nec (29); Electrical and optical equipment (30t33- available but dropped, see below); Transport equipment (34t35); Manufacturing nec, recycling (36t37); Electricity, gas and water supply $(\mathrm{E})$; Construction $(\mathrm{F})$; Wholesale and retail trade $(\mathrm{G})$; Hotels and restaurants $(\mathrm{H})$; Transport and storage (60t63); Post and telecommunications (64); Financial intermediation (J); Renting of m\&eq and other business activities (71t74).

4 This includes Germany due to the reunification process. 
the production chain (input providers) and does not necessarily become pure profit for the firm.

In our empirical approach, we choose a more direct measure of rent size in the spirit of Blanchard and Giavazzi (2003). Rent size $(R S)$ is measured for each observation (which combines the country, industry and year dimensions) by the log of the value added price relative to the GDP price $(r p) .{ }^{5}$ Through the fixed-effects $F E_{i}$, estimates are carried out in a within dimension, within from countryxindustry and industryxtime dimensions and also, for some estimates, from a countryxtime dimension. For this reason, the fact that all prices, and consequently relative prices, are equal to one, the base year (here the year 2000) poses no problem. In these within dimensions, we assume that an increase (a decrease) of $r p$, the log of the value added price relative to the GDP price, means an increase (a decrease) in rents.

Data on prices at industry level are available from 1960 in the OECD Stan dataset depending on the country and industry. Measuring prices is often difficult, especially in industries subject to substantial qualitative improvement over time. This is the case of the "Electrical and optical equipment" industry (30t33) which includes computers and communication equipment. In such cases there exist different methodologies between countries to construct relevant price indices which give very different results. ${ }^{6}$ For instance, for the US, the price in this industry was divided by a factor of six since 1980. For France it was halved whereas it increased in many countries, such as Korea, Spain and Italy. Such extreme differences are difficult to explain solely by different patterns of specialisation or technological change ${ }^{7}$ and measurement issues are a serious concern for this industry as a result. We choose to drop this industry from the analysis and include it as a robustness check. The results remain very similar (see section 6).

Of course, our relative price variable does not capture perfectly all sorts of rent in a given sector at any point in time. Prices can be fixed administratively in some sectors and a proportion of rents can be measured in terms of quantity such as the ratio of volume produced per unit of capital for instance. We believe that most rents translate into higher value added

From now on, we denote with lower case variables that stand for log values.

6 For instance, in the US national account, the hedonic method is used for these industries. This is not the case for most OECD countries.

7 Patterns of specialization and technological change should be quite similar among OECD countries even if we consider a low level of disaggregation. This is not the case if we compare the intra-industry pattern of specialization between OECD countries and developing countries (see Schott, 2003). 
prices. Indeed, our first step estimates show unambiguously that our indicators of rigidities on the product market have a very robust and strong impact on our relative price variable.

\subsubsection{Second step: rent sharing}

As we saw in the previous section, rents do not necessarily translate into higher profit, depending on which agent captures the rent. Focusing on the changes in the capital share allows us to determine to what extent rents translate into higher profit.

The capital share (CS) corresponds to the ratio of one minus the wage bill over value added:

$$
C S_{c s t}=\left(1-W_{c s t} \times L c s t\right) / V A_{c s t}
$$

Value added can be measured at market price value or at factor cost value. Factor cost value added is expressed by the market price VA, from which we subtract net taxes on production. The factor cost capital share seems more appropriated since it reports the real sharing between the two factors from the firm's point of view. We opt for this definition and compute the value added at factor cost using data on value added and "other taxes less subsidies on production" from the OECD.

An important issue - highlighted by Gollin (2002) for instance - is accounting accurately for the income of self-employed workers. Self-employed income is usually regarded as capital income. This downward biases the measure of the capital share and makes international comparisons difficult as the proportion of self-employed workers in the total workforce is very different from one country to another and may vary a lot over time (Nunziata, 2008). The most popular method for correcting the capital share is to apply a fictitious wage to selfemployed worker equivalent to the mean wage among employees. The number of selfemployed workers and the wage bill of employee are available at the industry level for OECD countries in the STAN dataset, allowing us to correct the capital share directly at the industry level for each country. ${ }^{8}$ Adjusting for self-employed workers is an important issue for our purposes: labour market regulations (included as regressors, see below) affect both the

\footnotetext{
This is important for measuring correctly the share of value added accruing to labour as the characteristics of
} self-employed workers differ across industries. 
unadjusted capital share and the number of self-employed (which in turn affect the unadjusted capital share).

According to this definition, the mean capital share across industries and countries is 0.33 (the value many economist have in mind). While the labour share appears to be quite stable at the aggregate level (see Blanchard, 1997, however) it exhibits important fluctuations at the industry level as the within standard deviation is around 5 percentage points. Young (2010), following Solow (1958), also highlights this relative constancy at the aggregate level but shows that the level of the labour share has changed a lot at the industry level over the period.

We also use an unadjusted measure of the labour share and a measure of the labour share at market prices as a robustness check and also directly control for the ratio of employees to total employment in regressions as an alternative method to take into account the selfemployed bias.

\subsection{The determinants of rent creation and rent sharing}

\subsubsection{Regulations on the product market}

Previous empirical research focusing on competition on the product market has used a variety of approaches to measure competitive pressures. These include indicators of market structure and/or market power, survey-based assessments of the business environment and indicators of product market policies. In this paper, we use product market regulation indicators alone. The reason is two-fold. First, the paper focuses on pure rent creation (and capture). This corresponds to super profits, not dissipated by entry costs for instance. Indicators of market structure or market power do not necessarily result in abnormal prices (rents): high market concentration does not necessarily imply high relative prices/mark-ups if markets are contestable that is, if potential incumbents make firms behave as if they were facing many competitors. Secondly, using regulation indicators minimises the endogeneity bias. Regulations on the product markets can be seen, to a large extent, as a discrete policy choice and should display better exogeneity properties. ${ }^{9}$

9 Of course, endogeneity cannot be completely ruled out with these indicators if, for instance, policies are affected by rent outcomes through political economy channels. On the relative advantages of policy-based and survey-based composite indicators, see Nicoletti and Pryor (2006). 
Direct anti-competitive regulation $(D A C R)$ measurement differs for manufacturing and non-manufacturing industries.

While few explicit barriers to competition remain in markets for manufacturing goods in OECD economies, this was not the case in the 1980s and the 1990s. During this period, markets continued to be protected from international competition. For manufacturing industries (which represent 2,342 observations out of the 4,136 in the whole sample), we use an import tax indicator (TARIFF) available from the OECD (see appendix for details). It starts in 1988 and ends in 2005. Following the OECD, it is assumed that the tariff is constant after this date. ${ }^{10}$ The tariff variable have been coded and takes values from 0 (low import tax) and 6 (high import tax). In practice, $25 \%$ of our sample takes value of 2 or higher and $10 \%$ of our sample takes a value of 3 or higher. The overall decrease in tariffs during the period under review is quite modest (0.6) on average but the decline can be much greater in many countries/industries.

The non-manufacturing industry is undoubtedly the most regulated and sheltered part of the economy. For non-manufacturing industries (1,794 observations), regulations are mainly measured by a FDI restriction indicator (FDIR). Another indicator, barriers to entry (ENTRY_REG), is also available for non-manufacturing industries, but only for a proportion of them ${ }^{11}$ (which represent 1,084 observations out of the 1,794 observations on nonmanufacturing industries in the dataset), and will be used alternatively as an illustration.

Entry regulation indicators $\left(E N T R Y \_R E G\right)$ are based on detailed information on laws, rules and market and industry settings and cover energy (gas and electricity), transport (rail, road and air) and communication (post, fixed and cellular telecommunications), retail distribution and professional services, with country and time coverage varying across industries. The indicators for energy, transport and communication are available from 1975 to 2007. The indicators for retail distribution and professional services are available for 1998, 2003 and 2007. Following the OECD, missing values are obtained using linear interpolation and regarding these regulations as constant before 1988 in these two industries. The banking entry

10 This assumption that ensures we work on the same sample in our two-step procedure (see below).

11 Mainly because the ENTRY indicator is not available for three industries: Construction (F), Hotels and Restaurants $(\mathrm{G})$ and Finance and Insurance ( $\mathrm{J}$ and $\mathrm{K})$. See section 2 for more details. 
index is available for one year only (2006) and this industry cannot be included in regressions using the entry regulation index. "Construction" and "Hotels and Restaurants" are not covered by ENTRY_REG indicators. The Entry regulation indicator may cover different types of restrictions. Entry regulations may concern capital and labour and this is not expected to have the same implications concerning the sharing of these rents. Restrictions on labour should favour workers in rent sharing. Nevertheless, we are not able to distinguish which of the two factors benefit most from the restrictions.

The OECD FDI regulatory restrictiveness index (FDI_RES, scaled from 0 to 6) measures different forms of discrimination against foreign firms, such as i) restrictions on foreign ownership, ii) obligatory screening and approval procedures for foreign affiliates and iii) operational constraints and controls for affiliates of foreign companies. This index is available for all non-manufacturing industries from 1981 to 2007. Over our sample, restrictions on FDI entry decrease sharply from 1988 onwards, $25 \%$ of our sample observations take values higher than 3.5 whereas in 2005, 25\% of our sample observation take values higher than 1 .

Of course, our three different indicators for DACR are different in nature and cover very different aspects of competition between firms. Nevertheless, we believe that they affect the ability of firms to set high prices as they all affect the degree of competition. In their imperfect competition framework, Blanchard and Giavazzi (2003), when considering product market reforms that may have impacted the labour share, include trade openness as well as local deregulation in order to favour the entry of new competitors.

Again, product market regulations aimed at limiting entry and competition not only affects industries directly, allowing firms to set high relative prices which generate rents, they also impact industry through the use of intermediate inputs.

To capture this idea, like Conway and Nicoletti (2006), we construct an indirect competition index (IND_price) based on our indicator of rents, namely relative industry value added prices. In order to identify the degree of exposure of a given industry to another industry's degree of competition, we use the Leontief input/output table from the OECD for the year 2000 for each country. ${ }^{12}$ The exposure of a given industry $k$ in country $c$ to other industry

12 To minimize endogeneity issues and measurement errors we also construct an indirect regulation index using the US input/output table as a robustness check (see section V). The results remain the same. 
prices is the sum of the price index in the $s$ other industries weighted by the Leontief coefficients of industry $k$ for input of industry $s$ ( $\left.w_{\text {cks }}\right)$. Note that we have excluded input consumption from the same industry (intra-input consumption) as rent is not captured by another industry in such a case but remains in the same industry. Formally, this gives:

$$
I N D \_ \text {price }=\Sigma_{s} \text { price }_{c s t} \times w_{c k s}
$$

As a robustness check and to avoid measurement errors in the input/output matrix, we also apply the US input/output matrix for all countries.

\subsubsection{Labour market characteristics}

The bargaining power of workers is theoretically expected to affect the sharing of value added. Nevertheless, the empirical counterpart of this concept is difficult to capture. If strong labour market institutions (LMI) favour workers in the capture of rent, they also impact the unemployment rate and deteriorate the probability for a worker to obtain a job offer, reducing his outside options and negatively impacting his bargaining position. ${ }^{13}$

The fact that LMI have an impact on employment opportunity is not clear in the empirical literature (Bassanini and Duval, 2009) and unemployment cannot be attributed exclusively to LMI. As a result, in order to capture all of the bargaining conditions for workers, we need indicators for labour market regulations and indicators that broadly reflect the employment equilibrium.

Labour market institutions have many dimensions and do not necessarily reflect cross-country differences in the (exogenous) bargaining power of workers. Furthermore, there may possibly be many complementarities between them (see Bassanini and Duval, 2009). Choosing a dimension is necessarily arbitrary and we have decided to use a composite index that we believe broadly reflects the (exogenous) bargaining conditions of workers, namely: the employment protection legislation (EPL) index of the OECD (scaled from 0 to 6). We mainly focus on the indicator for regular employment (EPL_REGULAR). We also use the overall index (EPL_OVERALL) which also includes regulations on temporary employment.

13 The positive direct effect of labour market institutions of course dominates the second negative indirect effect. See Pisarides (2000) for instance. 
Nevertheless, the effects of temporary employment regulations on labour market outcomes are not clear. ${ }^{14}$ The EPL index for regular jobs does not vary a lot within each country as the within standard deviation is only 0.10 as compared with the 0.80 of the between standard deviation. Nevertheless, the between dimension of this variable remains useful for our purposes as we interact it with rent size to highlight the capture process that is conditional on workers' bargaining power (see (2)).

We also choose to use the country unemployment rate for 25-54 year-old men, which broadly reflects the employment equilibrium and tensions in the labour market affecting bargaining power. Unemployment series are smoothed using an HP filter (using a smoothing parameter of 6.9) to save us from capturing reverse causality. Over the business cycle, a decrease in employment may be necessary to restore a firm's profitability as in the standard neoKeynesian framework. ${ }^{15}$ This variable varies considerably. $25 \%$ of unemployment rates observations are higher than $6.6 \%$ and $25 \%$ are lower than $3.8 \%$. This variable also varies a lot within each country over the period we consider as within standard deviation corresponds to two-thirds of the overall standard deviation. In some regressions, we alternatively include the smoothed unemployment rate for the whole population. In practice, using an HP filter does not affect the results.

All the variables relating to workers' bargaining power are only available at the country level. As regards institutional variables, while many regulations are set at country level, in many countries, such as Germany or Sweden, some of them are set at industry level. Nevertheless, regulation indices for labour at industry level are not yet available. One can argue that such a degree of freedom at industry level in some countries is subject to a more general standards/corpus of law and national regulations. When using these variables, timexcountries fixed-effects are dropped from regression. Including such a variable for bargaining power at the national level also saves us from capturing reverse causality as national development should to a large extent be exogenous to developments in a particular industry.

14 See Cahuc and Postel-Vinay (2002) or Blanchard and Landier (2002).

15 In practice, this affect results only marginally. Incidentally, we also control for the business cycle in the regressions (see below). We also focus mainly on the total unemployment rate as a robustness check. 


\subsubsection{Other determinants}

Many authors point to the role of the business cycle to explain the cyclical behaviour of the capital share and mark-up. Choi and Rios-Rull (2009) highlight the role of non competitive factor price to explain the movement of the labour share following a productivity shock. Rotemberg and Woodford (1991) and Chevalier and Scharfstein (1996) found that mark-up was countercyclical in the United States. In contrast, Beccarello (1995) found a pro-cyclical movement of mark-ups for major OECD countries except for the United States. Machin and Van Reenen (1993) also find that in the UK profit margins are clearly affected by the business cycle.

By contrast, we focus here on both the macro business cycle and the business cycle of each industry. We include in many of the regressions the output gap at industry level $\left(O G_{c s t}\right)$ and also at national level $\left(\mathrm{OG}_{\mathrm{ct}}\right)$ in order to control for country specific factors affecting capital share as timexcountry dummies are dropped from some regressions. The output gap is computed using an HP filter and following standard methodologies.

\section{RESULTS}

\subsection{Rent creation}

Because the measurement of direct anti-competitive regulation (DACR) differs for manufacturing and non-manufacturing industries, estimates are carried out separately for these two parts of the dataset. Table 1 gives the estimate results of the relation (1) for manufacturing and non-manufacturing industries.

As stated in the previous section, $D A C R$ is measured for manufacturing industries (which represent 2,342 observations out of the 4,136 in the whole sample) by an import tax indicator (TARIFF). For non-manufacturing industries (1,794 observations), it is mainly measured by a FDI restriction indicator (FDIR). Another indicator, barriers to entry (ENTRY), is also available for non-manufacturing industries, but only for a proportion of them ${ }^{16}$ (which

16 Mainly because the ENTRY indicator is not available for three industries: Construction (F), Hotels and Restaurants $(\mathrm{G})$ and Finance and Insurance ( $\mathrm{J}$ and $\mathrm{K})$. See section 2 for more details. 
represent 1,084 observations out of the 1,794 observations on non-manufacturing industries in the dataset), and will be used alternatively as an illustration.

Direct anti-competitive regulation $(D A C R)$ appears to have a positive and very significant impact (at a $1 \%$ threshold) on rent size (columns 1 to 4 ). In manufacturing and nonmanufacturing industries, an increase of the DACR indicator (TARIFF and FDIR respectively) by one point raises the relative value added price by around $3 \%$ and $2.5 \%$ respectively to $3 \%$. It appears that these results are robust to the fact that countryxtime fixed-effects are taken into account or not. In non-manufacturing industries, the coefficient of the ENTRY indicator appears not to be significant (columns 5 and 6). This result does not stem from the fact that the sample size differs, the ENTRY indicator being available for only a proportion of the nonmanufacturing observations in our dataset (1,084 out of 1,794 observations): estimates with the FDIR indicator on this reduced population of non-manufacturing industries give the same result as on non-manufacturing industries as a whole (columns 7 and 8).

For service activities where two indicators are available, the FDI restriction indicator unambiguously relates to restrictions on capital. On the other hand, the fact that restrictions on entry do not appear to have a significant impact on relative price may reflect the fact that the entry indicator covers too many different kind of restrictions.

These estimation results give a robust and convincing empirical confirmation that direct anticompetitive regulations $(D A C R)$ strongly impact the relative price, a variable we use to determine rent size $(R S)$. We will now try to explain the sharing process of these rents.

\subsection{The determinants of rent sharing}

In this section, we focus on various determinants of the capital share in the value added in each industry. Estimates will systematically include country-industry and industry-year dummies in order to capture exogenous heterogeneity.

\subsubsection{The product market}

First, the ability to charge higher prices thanks to the mechanisms set out in the previous section should translate into a higher capital share, if the bargaining power of workers is weak 
or moderate. We test this expectation directly. Columns 1 and 2 of table 2 report the correlation between the capital share and the relative price. Whether or not country-year dummies are included, the capital share is significantly and positively correlated with relative prices. A one percent increase in the relative price is associated with an improvement in the capital share of 0.15 percentage point in value added (suggesting that on average the bargaining power of workers is not strong).

Of course, the capital share and capital income do not correspond solely to rents. However, we can deduce from the impact of relative price (rents) on the capital share the sharing of pure rents. Let us take a simple example. Consider an initial capital share of 1/3 (2/3 for the labour share) as suggested by our descriptive statistics and a value added normalized at 100. Let us consider an increase of the value added price in a given sector of $10 \%$ corresponding to a pure rent, everything else being equal. Value added becomes 110 and our results indicate that the capital share reaches $34.5 \%$. This implies that total capital incomes in this sector increase from 33 to 38, which means that capital owners capture half of the extra rent.

Second, lower competition in upstream industries should lead to higher prices (see table 2) which translate (everything else equal) into lower rents (and lower capital share as a result) in client industries if the latter cannot fully convert it to their consumers or to their workers. The competitive environment among suppliers is capture by our weighted index IND_price for each industry-country-year observation. The introduction of this variable -lagged in order to limit potential spurious correlations and to take account of the stickiness of prices in suppliers' contracts- does not alter the relation between capital share and relative prices. Columns 3 and 4 in table 2 report significant correlations between the indirect price among suppliers and capital share. As expected, these correlations are negative. The magnitude of the potential effect is large: a one within standard deviation increase of indirect prices is associated with a 0.5 to 0.9 percentage point reduction of capital share in value added. According to these results a general movement of deregulation does not necessarily result in a lower capital share for a given industry since gains on suppliers may balance out losses in market power.

A final dimension of the product market environment is the business cycle. For example, lower demand vis-à-vis a given industry mechanically erodes rents. We thus introduce into the estimates the current output gap for each industry-country. The previous correlations are 
not affected by this introduction. Columns 5 to 8 in table 2 show that, as expected, the capital share is significantly related to the output gap at the industry level. The magnitude of the estimate is sizeable. A translation from Q1 to Q3 or a one within-standard-deviation increase of the output gap is associated with a roughly 1.2 percentage point reduction of the capital share in value added. However, using basic data, we do not observe that the capital share at the industry level necessarily changes with a general economic boom or downturn. Actually, the macro environment should affect rent sharing though mechanisms outside of the product market, especially the labour market.

\subsubsection{The labour market}

While the capital share is the complement of the labour share in value added, the internal and external labour market environments influence rent sharing. A capture of rents by workers translates into a decline of the capital share.

First, the outside options of workers and thus their individual and collective bargaining power is affected by the macroeconomic environment. They are improved in a boom and deteriorate in a bust. The national output gap is an index of the macroeconomic situation. In column 1 of table 3, we add this variable to previous estimates. It does not significantly distort previous results. The national output gap is clearly and, as expected, negatively correlated with the capital share. The magnitude of the estimated coefficient is similar to that for the industry output gap. Consequently, the net impact of the business cycle for an industry following the average for the economy is virtually nil on the capital share.

An alternative measure of the macro-environment for workers is the smoothed unemployment rate $(U N R S)$. We use the unemployment on the core labour force -men aged 25-54- or alternatively the total unemployment rate. ${ }^{17}$ The results are similar, which is not surprising given the large correlation between these two measures. Columns 2 to 4 of table 3 show that a one point increase in the lagged unemployment rate is associated with a 0.5 point jump in the capital share at industry level. Note again that this result is obtained conditionally on the industry output gap. So our results are not necessarily inconsistent with macro-observations of a contraction of the capital share during recessions.

17 We also tried an unemployment rate gap. The results are qualitatively similar. 
In addition to the short-term fluctuations of the labour market, institutions on the labour market may also affect the individual and collective bargaining power of workers and thus rent sharing. In column 5 of table 3, we introduce the aggregated index EPL_Overall computed by the OECD. The correlation between this macro index and the industry capital share is quite low but significant. This weak relation may be explained by the composition of the OECD index. In particular, even if workers on short-term contracts are strongly protected during this contract, they are not able to extract rents from the employer. Because they have specific human capitals or because they are able to organize their claims collectively, regular workers should be more able to influence their wage levels. And indeed, if we restrict our analysis to employment protection legislation for regular workers, we obtain a much stronger negative correlation between the protection of regular workers and capital share (column 6 , table 3) than the previous indicator of employment protection. The estimated coefficient is large. Thus, even if actual changes in the strength of the protection of regular workers are small, they can significantly affect rent sharing. According to our estimates, the liberalization of the labour market for regular workers in Spain may explain as much as a 4-point jump in the capital share in value added. Since empirical studies on labour market rigidities (Bassanini and Duval, 2009) tend to find that only regulations for short-term or temporary workers affect structural unemployment, our results suggest that reinforcing the protection of regular workers may help to improve the labour share without deteriorating the labour market. However, our results should be treated with caution: numerous countries in our sample experience no or very little changes over time in EPL_regular.

\subsubsection{Interaction between rent size and rent sharing}

In the two previous sub-sections, we estimate potential effects of regulations concerning suppliers, unemployment and labour market regulation based on the assumption that these effects are homogeneous. Now, rent sharing is, by definition, possible if, and only if, rents exist. So, we expect that the impacts of the identified determinants of rent sharing are larger in industries able to charge higher prices and conversely small and even nil in industries with declining relative prices. To test this expectation, we run various estimates including the interaction between the relative price and two of our three core determinants IND_price, UNRS, EPL_Regular. We do not interact price with our indirect price variable. Indeed, these two variables are centred on 0 . Even if one of the two variables is rescaled, the coefficient of 
the interaction between relative price and the indirect price is zero (not reported in the paper). This result is consistent with a world in which client firms in most industries are price-takers and suppliers cannot price discriminate between clients from industries with low versus high rents. Table 4 reports the main findings.

By contrast, the interactions between the relative price and the smoothed unemployment rate (men aged 25-54) and the EPL for regular workers seem significant determinants of the capital share. The higher relative prices and thus rents, the greater the net potential impact of the macro unemployment rate and of EPL_Regular. However, even if the relative price is at the decile D1 (-0.14), the net impacts are still significantly non-null. These findings are consistent with micro-estimates using an alternative measure of the bargaining power of workers. For example, Stewart (1990) on the US and Breda (2010) on France show that the union wage premium is higher in industries where rents are large.

As we have already stated, the ability of firms to translate higher relative prices into a higher capital share (profits) depends on the (macro) bargaining position of workers. A high EPL index or a low unemployment rate makes the impact of the relative price on the capital share smaller due to the fact that a large part of the rent is captured by workers through higher wages. Formally, the marginal impact $i_{P}$ of relative price (rents) on the capital share is $i_{p}=$ $\beta_{\text {price }}+\beta_{\text {price } \times \text { unr }}+\beta_{\text {pricexepl }}$ that is, the coefficient associated with prices and the coefficient associated with the two interaction terms. To see the range of values taken by the marginal effect of price $i_{P}$ on the capital share, a simple way is to fix one of the two bargaining variables (EPL or the unemployment rate) to its median value and to represent the marginal effect as a function of the remaining variable. The marginal effect of price on the capital share is represented as a function of the unemployment rate in graph 1 and as a function of EPL on regular jobs in graph 2. For instance, moving from the lowest value of unemployment $(1.5 \%)$ to the highest $(15 \%)$ multiplies the impact of the relative price on the capital share by 2 . Following the same logic, the marginal effect of the relative price on the capital share if 0.24 for the lowest EPL value (0.21) and 0.10 for the highest (evaluated at the median level of unemployment in our sample). These differences are economically large and suggest again that rents translate into profit depending on the bargaining power of workers. As Young and Zuleta (2011) highlights on US unions, these findings are consistent with a right-to-manage bargaining between workers and employers. 


\section{ROBUSTNESS ANALYSIS}

In this section, we access the robustness of our main results. We first perform inference more carefully by clustering standard errors. We then use a different measure of our dependent variable, namely the capital share. Finally we perform our main regressions on different subsamples. Almost all the results remain very stable.

\subsection{Clustering standard errors}

We define a cluster for each panel dimension (288 clusters). The heteroskedasticity is corrected within each cluster. Significance levels for the first-step estimates (rent building, table 1) remain essentially the same (not reported in the paper). Hence, we focus on step 2 (rent sharing).

In table 5, we run regressions of table 4 by clustering standard errors. Significance levels are roughly the same with one notable exception. The interaction term between the relative price and the EPL index of labour protection for regular jobs is no longer significant (significant at $20 \%$ ). Note, however, that the magnitude of the coefficient is economically high (see graph 2) and that the relative price and EPL for regular jobs taken separately are still highly significant. As a result, the sum of the two coefficients (interaction and non-interacted) should still remain significantly different from 0 .

\subsection{Measures of the capital share}

Measures of the capital share depend entirely on the convention we use. As explained above, in the main regressions we use the capital share measured at factor cost and adjusted for selfemployed workers (see section 3.1.2). As an alternative measure, we also use a naïve measure of the capital share that simply corresponds to the ratio of the wage bill of employees to the value added. We also use the capital share at factor cost without adjustment for self-employed workers. A complete description of the capital share variables is available in the appendix.

Before describing our results using these alternative measures of the capital share we comment on the descriptive statistics associated with each measure. 
First of all when focusing on the capital share at industry level it seems important to measure the capital share at factor cost. If, at the national level the sum of taxes and subsidies on production roughly cancel one another out (the two measures at national level differ only marginally) this is not the case at the industry level where value added can even be negative in some cases. The minimum value of the capital share can be negative at the industry level when we focus on the naïve measure. This is the case for 14 observations. This is not the case when we focus on the measure at factor cost, which seems therefore to be more appropriate as it measures the real dividing-up of the pie from the firm's point of view.

Secondly, adjusting the capital share to take account of the labour income of self-employed workers drives this factor share at the conventional level we have in mind (1/3 instead of $40 \%$ for the unadjusted share).

The results, displayed in table 6 , remain roughly the same when we use alternative measures of the capital share except for the interaction term between relative prices and EPL for regular workers. In column 2 (naïve) and 3 (factor cost), the magnitude of the coefficient is divided by 5 and remains insignificant. The reason for this surprising result, obtained on the same sample, is that the strictness of employment protection and self employment are correlated. Individuals avoid employment legislation using self employment. Since self-employment drives up the unadjusted capital share whereas employment legislation drives it down, adjusting capital share appears to be necessary in order to capture the net effect of EPL on the capital share. Interestingly, when we run regressions (2) and (3) adding a control for the share of employees in total employment, the interaction term becomes significant at $10 \%$ in regression (5). As expected, the coefficient associated with this variable is negative.

The reason why regression 5 (factor cost with a control for self-employment) does not perform as well as our preferred regression 1 is that including a control for self-employment at the industry level is only a crude means for correcting the capital share. The sign of the coefficient (adjustment) is constrained to be the same for all industries. This is not the case when we directly adjust the capital share applying the mean wage of employees in the industry to each self-employed working in the industry.

The magnitude of the coefficient associated with the interaction term between the relative price and unemployment is also affected (divided by two) when using the two alternative 
measures of the capital share but remains highly significant. For the same reason, the unemployment level may affect workers in their choice of searching for a job as an employee or becoming self-employed.

\subsection{Others robustness checks}

Table 7 and table 8 present the results of additional robustness checks consisting in running our main regression (1) using alternative samples, including additional fixed effects and alternative variables.

\subsubsection{Country groups}

We first consider in table 7 an alternative specification for the country dimension. The first column corresponds to our preferred estimates on the sample we used previously (table 4, column 3).

In column 2, we run our main regression only focusing on the highest-income countries. ${ }^{18}$ The results remain unchanged except for the interaction term between the relative price and the unemployment rate. The magnitude of the coefficient is divided by three and becomes insignificant. This could be due to the fact that standard deviation for the unemployment rate variable is very low for high-income countries.

In column 3, we also run the main regression on the lower income group of countries. Noninteracted variables do not seem to be significant anymore except for the price variable and business cycle variables. However, interacted variables appear to be statistically significant with a very high coefficient from an economic point of view. This could reflect considerable heterogeneity of rents across industries in lower income economies explaining the fact that rent capture is not systematic (non-interacted terms) and only occurs in some industries characterized by high rents.

18 We include in the very high income group, countries with the highest GDP per capita in 2000, which correspond to roughly one-half of our sample: the USA, Norway, Denmark, Austria, the Netherlands, Belgium and the United Kingdom. 
In column 4, we add country-specific time dummies to the regressions and drop the countryspecific variables of our main regression. Note that we can keep the interaction term as relative prices vary over the three dimensions of our panel. Interestingly, the results remain very robust to the inclusion of such fixed effects despite the fact that the components of the interaction terms do not vary across industries. The coefficient associated with the interaction of price with the EPL index is divided by two and remains significant only at the $15 \%$ level. The coefficient for the indirect price index remains significant at the $10 \%$ level.

In column 5 we restrict the observations to the more recent 1998-2007 sub-period that is homogenous for all countries in our sample. The results remain very significant and the magnitude of coefficients is even higher.

In column 6, we only keep countries with complete industry coverage. The results remain unchanged except for the interaction of the relative price with EPL. The coefficient is divided by two and remains non significant despite the fact that price and EPL taken separately remain highly significant. One explanation could be that by only keeping countries with complete industry coverage we exclude lower income economies that have undertaken substantial labour market reforms. Nevertheless the sum of interacted and non interacted coefficient continues to be highly significant.

\subsubsection{Manufacturing versus non-manufacturing industries, an alternative input/output matrix}

We then consider an alternative specification for the country dimension. The results are presented in table 8 . The first column corresponds to our preferred estimates over the sample we used previously.

In columns 2 and 3, we run our main regression separately for non-manufacturing (construction, utilities and services) and manufacturing industries. While overall the results hold for the two subsamples, one important difference concerns the unemployment rate and its interaction with the relative price. For non-manufacturing industries, the coefficient associated with unemployment is more than 2 times smaller than for manufacturing industries (but remains highly significant) and the interaction term remains 4 times smaller and becomes insignificant. This difference is consistent with manufacturing's greater sensitivity to the 
business cycle compared with non-manufacturing industries, especially utilities and personal services.

It should be recalled that we have excluded from the main sample the "Electrical and optical equipment" industry (30t33) whose prices are measured very differently across countries. Therefore, as an additional check, in column 4, we add this industry to our sample. This essentially effects interaction terms as it adds many noisy fluctuations to the relative price variable with respect to the unemployment and EPL variables. The interaction of the relative price and EPL remains significant but the magnitude of the associated coefficient is halved. The interaction of the relative price and unemployment is no longer significant.

Finally, in column 5, we use the input/output of the US in the construction of our indirect price variable for all countries in order to deal with measurement issues. In column 6, we proceed similarly and we also drop US from the sample in order to deal with the endogeneity issue. In both cases, the results are unaltered.

Overall, our main findings are robust to the various sensitivity checks performed in this subsection.

\section{POLICY PERSPECTIVES}

The estimates based on 4,136 observations, comprising data on 18 industries in 17 OECD countries over the period 1988 to 2007 help to disentangle different mechanisms relating to rent creation and rent sharing. Our results have various potential policy implications, since prices and rents are both determinants of consumption and innovation and thus ultimately growth.

Concerning the rent creation step, our results support the finding that direct anti-competitive regulation has a positive and very significant impact on prices. Conversely, we can expect that a decrease of anti-competitive regulation should reduce prices at the industry level, ultimately boosting consumption. 
The rent sharing step provides numerous results. They support the existence of the three destinations for rents (labour remuneration, capital remuneration and upstream industries) and the fact that the importance of each destination depends on the market power of its beneficiary. It appears that the capital share in value added i) increases with rent size, decreases with anti-competitive regulation in upstream sectors and increases with the industry specific output gap; ii) decreases with employment protection regulation; iii) increases with the interaction of rent size and the unemployment rate and decreases with the interaction of rent size and employment protection regulations. Consequently a decrease of upstream regulations could increase the downstream capital share in value added and consequently affect the incentive to innovate in these industries; acting on labour market regulations could be a tool for influencing the sharing between labour and capital and thus also the trade-off between enhancing profits and workers' income. Finally, our results show that the capital share within industries is affected by the business cycle, suggesting additional room for contra-cyclical policies.

Nevertheless, although they are innovative, consistent with economic intuition and very robust to sensitivity checks, our results need to receive some empirical corroboration on other databases e.g. a companies database. In addition, our two-step empirical estimates assume the same two relations in all countries and all industries. These findings need to be confirmed before considering that their policy implications can be easily applied to all countries. 


\section{REFERENCES}

- P. Aghion and P. Howitt (2009): The Economics of Growth, The MIT Press, Cambridge.

- J. Arnold, B. Javorcik and A. Mattoo (2011): "Does Services Liberalization Benefit Manufacturing Firms? Evidence from the Czech Republic," Journal of International Economics, vol. 85(1), pages 136-146.

- G. Azmat, A. Manning and J. Van Reenen (2011): "Privatization, Entry Regulation and the Decline of Labour's share of GDP: A Cross-country analysis of the Network Industries", Economica, forthcoming.

-Th. Breda (2010): “Firms' rents, workers' bargaining power and the union wage premium in France”, PSE working paper 2010-25.

- A. Bassanini and R. Duval (2009): "Unemployment, Institutions, and Reform Complementarities: re-assessing the aggregate evidence for OECD countries", Oxford Review of Economic Policy, 25, pp. 40-59.

- M. Beccarello (1996): "Time Series Analysis of Market Power: Evidence from G-7 Manufacturing”, International Journal of Industrial Organization, 15, pp 123-136.

- O. Blanchard and F. Giavazzi (2003): "Macroeconomic effects of regulation and deregulation in goods and labor markets", The Quarterly Journal of Economics, August, pp. 879-907.

- O. Blanchard and A. Landier (2002): "The Perverse Effects of Partial Labour Market Reform: Fixed Duration Contracts in France", The Economic Journal, 112, pp. 214-244.

- R. Bourles, G. Cette, J. Lopez, J. Mairesse and G. Nicoletti (2010): "Do Product Market Regulations in Upstream Industries Curb Productivity Growth ? Panel Data Evidence for OECD Countries", NBER, Working Paper Series, $n^{\circ}$ 16520, November. 
- P. Cahuc and F. Postel-Vinay (2002): “Temporary Jobs, Employment Protection and Labor Market Performance", Labour Economics, (9)1, pp. 63-91.

- J. Chevalier and D. Scharfstein (1996): "Capital-Market Imperfections and Countercyclical Markups: Theory and Evidence”, American Economic Review, 86, pp. 703725.

- S. Choi and J. Rios-Rull (2009): "Understanding the Dynamics of Labor Share: The Role of Noncompetitive Factor Prices", Annales d'Economie et Statistique, 95/96.

- P. Conway and G. Nicoletti (2006): "Product Market Regulation in the Non-Manufacturing Industries of OECD Countries: Measurement and Highlights”, OECD Economics Department Working Papers No. 530.

- D. Gollin (2002): "Getting Income Share Right", Journal of Political Economy, 110, pp. 458-475.

- S. Golub and T. Koyama (2006): “OECD's FDI Regulatory Restrictiveness Index: Revision and Extension to more Economies", OECD Economics Department Working Papers No 525, OECD, Paris.

- S. Machin and J. Van Reenen (1993): "Profit Margins and the Business Cycle: Evidence from UK Manufacturing Firms", The Journal of Industrial Economics, Vol. 41, No. 1 (Mar., 1993), pp. 29-50.

- G. Nicoletti, F. Pryor (2006): "Subjective and Objective Measures of Governmental Regulations in OECD nations", Journal of Economic Behaviour and Organization, 59, pp. 433-449.

- G. Nicoletti and S. Scarpetta (2003): "Regulation, Productivity and Growth. Economic Policy”, 36, pp. 11-72.

- L. Nunziata (2009): “Aggregate Self-Employment Patterns”, University of Padova Working Paper. 
- C. Pissarides (2000): Equilibrium Unemployment Theory. MIT Press, Cambridge, 2nd edition.

- J. Rotemberg and M. Woodford (1991): "Markups and the business cycle", NBER Macroeconomics Annual, 6, pp 63-129.

- P. Schott (2003): “One size fits all? Heckscher-Ohlin Specialization in Global Production”, American Economic Review, 93, pp. 686-708.

- R. Solow (1958): “A skeptical note on the constancy of relative shares," American Economic Review, 48, pp 618-631.

- D. Spector (2004): "Competition and the capital-labor conflict", European Economic Review, 48, pp. 25-48.

- M. Stewart (1990). "Union wage differentials, product market influences and the division of rents", The Economic Journal, 100(403), p. 1122-1137.

- J. Van Reenen (1996): “The Creation and Capture of Rents: wages and Innovation in a Panel of U.K. companies", The Quarterly Journal of Economics, Vol. 111, Issue 1, February, pp. 195-226.

- A. Young (2010): “One of the thing we know that ain't so: Is US labor's share relatively stable?”, Journal of Macroeconomics, 32, pp.90-102.

- A. Young and H. Zuleta (2011): "Do Unions Increase Labor's Shares? Evidence from US Industry-Level Data", mimeo. 


\section{APPENDIX}

\section{Details of variables: Content and sources}

Relative price: $\log ($ Value added prices/GDP price) using price series from STAN dataset. Source: OECD and own computations.

Share of employees: Employees/total employment. Source: OECD.

OTXS: Indirect taxes less subsidies on production. Source: OECD.

Capital share: Capital share adjusted for self-employed workers, at factor cost.. Source: OECD and own computation. With:

$$
C S_{c s t}=\left(1-\left(W_{c s t} \times L_{c s t}\right) \times\left(1 / S o E_{c s t}\right)\right) /\left(V A_{c s t}-O T X S_{c s t}\right)
$$

Import tax (0-6): The computation of the average tariff starts on the 6-digit level of the harmonised system product classification, with the tariff being defined as the ad valoren tariff rates applied to the most favoured nation. Tariff data have been aggregated into indicators for 2-digit ISIC Rev 3 industries using import-based weights, similarly as has been done in Nicoletti and Scarpetta (2003). Source: OECD.

Entry regulation (0-6): Entry regulation indicators are based on detailed information on laws, rules and market and industry standards and cover energy (gas and electricity), transport (rail, road and air) and communication (post, fixed and cellular telecommunications), retail distribution and professional services, with country and time coverage varying across industries. Following Bourles et al. (2010), the entry regulation index in a industry composed of sub-industries is the mean of the index of sub-industries. This is the case for Energy (composed of gas and electricity), transport (composed of rail, road and air) and communication (composed of post and telecom). Source: OECD.

FDI_restriction (0-6): The FDI restrictiveness index is composed of three sub-indicators: $i$ ) restrictions on foreign ownership, $i$ i) obligatory screening and approval procedures for foreign 
affiliates and iii) operational constraints or controls for affiliates of foreign companies. The FDI indicator is mainly based on information from the GATS commitments and country submissions to the OECD Code of Liberalisation of Capital movements (See Golub and Koyama, 2006). Source: OECD.

Indirect_price (0-6): It corresponds to the sum of prices of all other industries weighted by the input/output Leontief coefficient: $\left(\sum_{s-k}\right.$ price $_{c s t} \times w_{c k s}$. Source: OECD and own computations.

Employment protection legislation_(overall) (0-6): Synthetic indicators of the strictness of regulation on dismissals and the use of temporary contracts. Source: OECD.

Employment protection legislation_(regular) (0-6): Synthetic indicator of the strictness of regulation on dismissals on regular employment. Source: OECD.

Unemployment rate (25-54, men, smoothed): Unemployment rate (/100) for 25-54 year-old men, smoothed using an HP filter. HP filter parameter $\lambda=6.9$. Source: OECD and own computations.

Unemployment rate (smoothed): Overall unemployment rate (/100), smoothed using an HP filter. HP filter parameter $\lambda=6.9$. Source: $O E C D$ and own computations.

Industry output gap and National output gap: Output Gap at industry level and for the whole economy (/100). Obtained using value added series from the STAN dataset and using an HP filter. HP filter parameter $\lambda=6.9$. Source: $O E C D$ and own computations. 
Table A1_1

Descriptive statistics

\begin{tabular}{|c|c|c|c|c|c|}
\hline Variable & $\begin{array}{l}\text { Notation } \\
\text { In tables }\end{array}$ & & Mean & $\begin{array}{l}\text { Stand. } \\
\text { dev. }\end{array}$ & $\mathbf{N}$ \\
\hline \multirow{3}{*}{ Capital share (Factor cost, adjusted) } & & Overall & 0.3331 & 0.1499 & 4,136 \\
\hline & & Between & & 0.1448 & \\
\hline & & Within & & 0.0451 & \\
\hline \multirow[t]{3}{*}{ Capital share (Factor cost, unadjusted) } & & Overall & 0.3964 & 0.1351 & 4,136 \\
\hline & & Between & & 0.1303 & \\
\hline & & Within & & 0.0416 & \\
\hline \multirow[t]{3}{*}{ Capital share (Unadjusted) } & & Overall & 0.4038 & 0.1399 & 4,136 \\
\hline & & Between & & 0.1346 & \\
\hline & & Within & & 0.0424 & \\
\hline \multirow[t]{3}{*}{ Relative Price } & Price & Overall & 0.0009 & 0.1328 & 4,136 \\
\hline & & Between & & 0.0820 & \\
\hline & & Within & & 0.1050 & \\
\hline \multirow{3}{*}{$\begin{array}{l}\text { Import_Tax } \\
{[0 ; 6]}\end{array}$} & TARIFF & Overall & 1.2733 & 1.3222 & 2,342 \\
\hline & & Between & & 1.2950 & \\
\hline & & Within & & 0.4338 & \\
\hline \multirow{3}{*}{$\begin{array}{l}\text { FDI_restriction } \\
{[0 ; 6]}\end{array}$} & FDI_RES & Overall & 1.1552 & 1.3230 & 1,794 \\
\hline & & Between & & 1.0996 & \\
\hline & & Within & & 0.6876 & \\
\hline \multirow{3}{*}{$\begin{array}{l}\text { Entry_regulations } \\
{[0 ; 6]}\end{array}$} & ENTRY_REG & Overall & 2.6137 & 1.5823 & 1,084 \\
\hline & & Between & & 1.0979 & \\
\hline & & Within & & 1.1784 & \\
\hline \multirow[t]{3}{*}{ Indirect_price } & & Overall & 0.0022 & 0.0171 & 4,136 \\
\hline & & Between & & 0.0095 & \\
\hline & & Within & & 0.0139 & \\
\hline \multirow[t]{3}{*}{ Industry Output Gap } & OGS & Overall & 0.0007 & 0.0341 & 4,136 \\
\hline & & Between & & 0.0040 & \\
\hline & & Within & & 0.0339 & \\
\hline \multirow[t]{3}{*}{ National Output Gap } & $\mathrm{OG}$ & Overall & 0.0004 & 0.0103 & 4,136 \\
\hline & & Between & & 0.0015 & \\
\hline & & Within & & 0.0102 & \\
\hline \multirow[t]{3}{*}{ Unemployment rate (e, smoothed) } & UNRS_M2554 & Overall & 0.0555 & 0.0209 & 4,136 \\
\hline & & Between & & 0.0159 & \\
\hline & & Within & & 0.0129 & \\
\hline \multirow[t]{3}{*}{ Unemployment rate (smoothed) } & UNRS & Overall & 0.0695 & 0.0251 & 4,136 \\
\hline & & Between & & 0.0216 & \\
\hline & & Within & & 0.0130 & \\
\hline \multirow{3}{*}{$\begin{array}{l}\text { Employment protection legislation, } \\
\text { overall } \\
{[0 ; 6]}\end{array}$} & EPL_OVERALL & Overall & 2.0423 & 0.8347 & 4,136 \\
\hline & & Between & & 0.7489 & \\
\hline & & Within & & 0.2615 & \\
\hline \multirow{3}{*}{$\begin{array}{l}\text { Employment protection legislation, } \\
\text { regular } \\
{[0 ; 6]}\end{array}$} & EPL_REGULAR & Overall & 2.1360 & 0.8238 & 4,136 \\
\hline & & Between & & 0.7624 & \\
\hline & & Within & & 0.1053 & \\
\hline \multirow[t]{3}{*}{ Share of employees } & SoE & Overall & 0.9119 & 0.0889 & 4,136 \\
\hline & & Between & & 0.0909 & \\
\hline & & Within & & 0.0135 & \\
\hline
\end{tabular}


Table A1-2

Descriptive statistics

\begin{tabular}{|c|c|c|c|c|c|c|c|}
\hline Variable & D1 & Q1 & Median & Q3 & D9 & Min & Max \\
\hline Capital share (Factor cost, adjusted) & 0.1677 & 0.2302 & 0.3115 & 0.4048 & 0.5462 & 0.0011 & 0.8399 \\
\hline $\begin{array}{l}\text { Capital share (Factor cost, } \\
\text { unadjusted) }\end{array}$ & 0.2355 & 0.3010 & 0.3782 & 0.4751 & 0.5777 & 0.0263 & 0.8399 \\
\hline Capital share (Unadjusted) & 0.2436 & 0.3104 & 0.3891 & 0.4865 & 0.5840 & -0.4798 & 0.8523 \\
\hline Relative Price & -0.1391 & -0.0574 & 0 & 0.0539 & 0.1392 & -0.6872 & 1.0532 \\
\hline $\begin{array}{l}\text { Import_Tax } \\
{[0 ; 6]}\end{array}$ & 0 & 0 & 1 & 2 & 3 & 0 & 6 \\
\hline $\begin{array}{l}\text { FDI_restriction } \\
{[0 ; 6]}\end{array}$ & 0.132 & 0.1849 & 0.6678 & 1.5878 & 2.7000 & 0 & 6 \\
\hline $\begin{array}{l}\text { Entry_regulations } \\
{[0 ; 6]}\end{array}$ & 0.7185 & 1.3472 & 2.4990 & 3.6767 & 4.6718 & 0 & 6 \\
\hline $\begin{array}{l}\text { Indirect_price } \\
{[0 ; 6]}\end{array}$ & -0.0144 & -0.0055 & 0 & 0.0076 & 0.0199 & -0.0774 & 0.1038 \\
\hline Industry Output Gap & -0.0376 & -0.0165 & 0.0008 & 0.0187 & 0.0403 & -0.1950 & 0.4647 \\
\hline National Output Gap & -0.0100 & -0.0062 & -0.0006 & 0.0056 & 0.0131 & -0.0379 & 0.0511 \\
\hline $\begin{array}{l}\text { Unemployment rate (25-54, men, } \\
\text { smoothed) }\end{array}$ & 0.0321 & 0.0383 & 0.0520 & 0.0673 & 0.0854 & 0.0211 & 0.1310 \\
\hline Unemployment rate (smoothed) & 0.0400 & 0.0483 & 0.0649 & 0.0878 & 0.1039 & 0.0307 & 0.1475 \\
\hline $\begin{array}{l}\text { Employment protection legislation, } \\
\text { overall } \\
{[0 ; 6]}\end{array}$ & 0.6000 & 1.6200 & 2.1500 & 2.6900 & 3.9800 & 0.21 & 3.57 \\
\hline $\begin{array}{l}\text { Employment protection legislation, } \\
\text { regular } \\
{[0 ; 6]}\end{array}$ & 0.9500 & 1.7300 & 2.3100 & 2.7900 & 3.0500 & 0.17 & 3.31 \\
\hline Share of employees & 0.8043 & 0.8763 & 0.9399 & 0.9751 & 0.9939 & 0.4579 & 1 \\
\hline
\end{tabular}


Table 1

Effect of regulations on relative prices (Rent Creation)

\begin{tabular}{|c|c|c|c|c|c|c|c|c|}
\hline & (1) & (2) & (3) & (4) & (5) & (6) & (7) & (8) \\
\hline Import_Tax $_{\text {cst-1 }}$ & $\begin{array}{l}0.0327^{* * *} \\
(0.00655)\end{array}$ & $\begin{array}{l}0.0349^{* * *} \\
(0.00595)\end{array}$ & & & & & & \\
\hline FDI_Restriction $_{\text {cst-1 }}$ & & & $\begin{array}{l}0.0371^{* * *} \\
(0.00624)\end{array}$ & $\begin{array}{l}0.0331^{* * *} \\
(0.00627)\end{array}$ & & & $\begin{array}{l}0.0325^{\text {**** }} \\
(0.00645)\end{array}$ & $\begin{array}{l}0.0320^{* * *} \\
(0.00706)\end{array}$ \\
\hline Entry_regulation $_{\text {cst-1 }}$ & & & & & $\begin{array}{c}-0.0000608 \\
(0.00455)\end{array}$ & $\begin{array}{c}0.00275 \\
(0.00491)\end{array}$ & & \\
\hline \multicolumn{9}{|l|}{ Fixed effects } \\
\hline Country $\times$ Industry & Yes & Yes & Yes & Yes & Yes & Yes & Yes & yes \\
\hline Industry $\times$ Time & Yes & Yes & Yes & Yes & Yes & Yes & Yes & yes \\
\hline Country $\times$ Time & No & Yes & No & Yes & No & Yes & No & yes \\
\hline $\mathbf{N}$ & 2342 & 2342 & 1794 & 1794 & 1084 & 1084 & 1084 & 1084 \\
\hline Groups & 164 & 164 & 124 & 124 & 75 & 75 & 75 & 75 \\
\hline $\mathbf{R}^{2}$ within & 0.3702 & 0.5201 & 0.6022 & 0.6917 & 0.6422 & 0.7637 & 0.6576 & 0.7728 \\
\hline
\end{tabular}

Robust Standard errors in parentheses, ${ }^{*} p<0.10,{ }^{* *} p<0.05,{ }^{* * *} p<0.01$ 
Table 2

Rent sharing (1). Dependent variable: capital share (Factor cost, adjusted)

\begin{tabular}{|c|c|c|c|c|c|c|c|c|}
\hline & (1) & (2) & (3) & (4) & (5) & (6) & (7) & (8) \\
\hline Relative_price $_{\text {cst }}$ & $\begin{array}{l}0.139^{* * *} \\
(0.0113)\end{array}$ & $\begin{array}{l}0.159^{* * *} \\
(0.0110)\end{array}$ & $\begin{array}{l}0.143^{* * *} \\
(0.0110)\end{array}$ & $\begin{array}{l}0.158^{* * * *} \\
(0.0112)\end{array}$ & $\begin{array}{l}0.166^{* * *} \\
(0.0112)\end{array}$ & $\begin{array}{l}0.190^{* * *} \\
(0.0109)\end{array}$ & $\begin{array}{l}0.171^{* * *} \\
(0.0110)\end{array}$ & $\begin{array}{l}0.189^{* * *} \\
(0.0110)\end{array}$ \\
\hline Indirect_price $_{\text {cst-1 }}$ & & & $\begin{array}{c}-0.298^{* * *} \\
(0.0815)\end{array}$ & $\begin{array}{c}-0.147 \\
(0.115)\end{array}$ & & & $\begin{array}{l}-0.336^{* * *} \\
(0.0761)\end{array}$ & $\begin{array}{l}-0.176^{\circ} \\
(0.108)\end{array}$ \\
\hline Industry output_gap cst & & & & & $\begin{array}{l}0.416^{* * * *} \\
(0.0243)\end{array}$ & $\begin{array}{l}0.460^{* * *} \\
(0.0232)\end{array}$ & $\begin{array}{l}0.420^{* * *} \\
(0.0241)\end{array}$ & $\begin{array}{l}0.461^{* * *} \\
(0.0231)\end{array}$ \\
\hline \multicolumn{9}{|l|}{ Fixed effects } \\
\hline Country $\times$ Industry & Yes & Yes & Yes & Yes & Yes & Yes & Yes & Yes \\
\hline Industry $\times$ Time & Yes & Yes & Yes & Yes & Yes & Yes & Yes & Yes \\
\hline Country $\times$ Time & No & Yes & No & Yes & No & Yes & No & Yes \\
\hline $\mathbf{N}$ & 4136 & 4136 & 4136 & 4136 & 4136 & 4136 & 4136 & 4136 \\
\hline Nb Groups & 288 & 288 & 288 & 288 & 288 & 288 & 288 & 288 \\
\hline $\mathbf{R}^{2}$ within & 0.3197 & 0.4584 & 0.3243 & 0.4588 & 0.3931 & 0.5340 & 0.3989 & 0.5347 \\
\hline
\end{tabular}

Robust Standard errors in parentheses, ${ }^{*} p<0.10,{ }^{* *} p<0.05,{ }^{* * *} p<0.01$ 
Table 3

Rent sharing (2). Dependent variable: capital share (Factor cost, adjusted)

\begin{tabular}{|c|c|c|c|c|c|c|}
\hline & (1) & (2) & (3) & (4) & (5) & (6) \\
\hline Relative_price $_{\text {cst }}$ & $\begin{array}{l}0.176^{* * * *} \\
(0.0108)\end{array}$ & $\begin{array}{l}0.171^{* * * *} \\
(0.0108)\end{array}$ & $\begin{array}{l}0.175^{* * * *} \\
(0.0107)\end{array}$ & $\begin{array}{l}0.177^{* * *} \\
(0.0107)\end{array}$ & $\begin{array}{l}0.174^{* * *} \\
(0.0107)\end{array}$ & $\begin{array}{l}0.176^{* * *} \\
(0.0107)\end{array}$ \\
\hline Indirect_price ${ }_{\text {cst-1 }}$ & $\begin{array}{l}-0.334^{* * *} \\
(0.0755)\end{array}$ & $\begin{array}{l}-0.381^{\text {*** }} \\
(0.0738)\end{array}$ & $\begin{array}{l}-0.375^{* * *} \\
(0.0737)\end{array}$ & $\begin{array}{l}-0.382^{* * * *} \\
(0.0745)\end{array}$ & $\begin{array}{l}-0.376^{* * *} \\
(0.0736)\end{array}$ & $\begin{array}{l}-0.375^{\text {**** }} \\
(0.0739)\end{array}$ \\
\hline UNRS_M2554 $4_{\text {ct-1 }}$ & & $\begin{array}{l}0.687^{* * * *} \\
(0.0585)\end{array}$ & $\begin{array}{l}0.629^{* * *} \\
(0.0594)\end{array}$ & & $\begin{array}{l}0.597^{* * *} \\
(0.0615)\end{array}$ & $\begin{array}{l}0.588^{* * *} \\
(0.0599)\end{array}$ \\
\hline $\mathbf{U N R S}_{\mathrm{ct}-1}$ & & & & $\begin{array}{l}0.626^{* * *} \\
(0.0636)\end{array}$ & & \\
\hline EPL_OVERALL ${ }_{\mathrm{ct}-1}$ & & & & & $\begin{array}{c}-0.00653^{* *} \\
(0.00305)\end{array}$ & \\
\hline EPL_REGULAR ct-1 $_{1}$ & & & & & & $\begin{array}{l}-0.0291^{* * *} \\
(0.00619)\end{array}$ \\
\hline Industry output_gap cst & $\begin{array}{l}0.474^{* * * *} \\
(0.0247)\end{array}$ & $\begin{array}{l}0.437^{* * * *} \\
(0.0236)\end{array}$ & $\begin{array}{l}0.473^{* * * *} \\
(0.0244)\end{array}$ & $\begin{array}{l}0.474^{* * * *} \\
(0.0245)\end{array}$ & $\begin{array}{l}0.472^{* * * *} \\
(0.0244)\end{array}$ & $\begin{array}{l}0.474^{* * *} \\
(0.0245)\end{array}$ \\
\hline National output_gap ${ }_{c t}$ & $\begin{array}{l}-0.652^{* * *} \\
(0.0909)\end{array}$ & & $\begin{array}{l}-0.451^{* * *} \\
(0.0910)\end{array}$ & $\begin{array}{l}-0.471^{* * *} \\
(0.0917)\end{array}$ & $\begin{array}{l}-0.446^{* * *} \\
(0.0908)\end{array}$ & $\begin{array}{l}-0.428^{* * *} \\
(0.0910)\end{array}$ \\
\hline \multicolumn{7}{|l|}{ Fixed effects } \\
\hline Country $\times$ Industry & Yes & Yes & Yes & Yes & Yes & Yes \\
\hline Industry $\times$ Time & Yes & Yes & Yes & Yes & Yes & Yes \\
\hline $\mathbf{N}$ & 4136 & 4136 & 4136 & 4136 & 4136 & 4136 \\
\hline Nb Groups & 288 & 288 & 288 & 288 & 288 & 288 \\
\hline $\mathbf{R}^{2}$ within & 0.4095 & 0.4280 & 0.4328 & 0.4300 & 0.4337 & 0.4366 \\
\hline
\end{tabular}

Robust Standard errors in parentheses, ${ }^{*} p<0.10,{ }^{* *} p<0.05,{ }^{* * *} p<0.01$ 
Table 4

Rent sharing, interaction terms. Dependent variable: capital share (Factor cost, adjusted)

\begin{tabular}{|c|c|c|c|c|c|}
\hline & (1) & (2) & (3) & (4) & (5) \\
\hline Relative_price $_{\text {cst }}$ & $\begin{array}{l}0.122^{* * * *} \\
(0.0193)\end{array}$ & $\begin{array}{l}0.244^{* * * *} \\
(0.0247)\end{array}$ & $\begin{array}{l}0.189^{* * * *} \\
(0.0289)\end{array}$ & $\begin{array}{l}0.240^{* * * *} \\
(0.0242)\end{array}$ & $\begin{array}{l}0.186^{* * * *} \\
(0.0301)\end{array}$ \\
\hline Indirect_price $_{\text {cst-1 }}$ & $\begin{array}{l}-0.358^{* * *} \\
(0.0734)\end{array}$ & $\begin{array}{l}-0.383^{* * * *} \\
(0.0736)\end{array}$ & $\begin{array}{l}-0.366^{* * *} \\
(0.0732)\end{array}$ & $\begin{array}{c}-0.370^{* * *} \\
(0.0729)\end{array}$ & $\begin{array}{l}-0.354^{* * * *} \\
(0.0727)\end{array}$ \\
\hline UNRS_M2554 ct-1 $_{1}$ & $\begin{array}{l}0.559^{* * * *} \\
(0.0607)\end{array}$ & $\begin{array}{l}0.591^{* * * *} \\
(0.0601)\end{array}$ & $\begin{array}{l}0.562^{* * *} \\
(0.0608)\end{array}$ & $\begin{array}{l}0.591^{* * * *} \\
(0.0615)\end{array}$ & $\begin{array}{l}0.565^{* * * *} \\
(0.0627)\end{array}$ \\
\hline EPL_REGULAR Rt-1 $_{\text {ct }}$ & $\begin{array}{l}-0.0292^{* * *} \\
(0.00619)\end{array}$ & $\begin{array}{l}-0.0274^{* * *} \\
(0.00628)\end{array}$ & $\begin{array}{l}-0.0275^{* * *} \\
(0.00628)\end{array}$ & & \\
\hline EPL_OVERALL $L_{\text {ct-1 }}$ & & & & $\begin{array}{l}-0.00584^{*} \\
(0.00305)\end{array}$ & $\begin{array}{l}-0.00590^{*} \\
(0.00304)\end{array}$ \\
\hline Price $_{\text {cst }} \times$ UNRS_M255 & $\begin{array}{l}1.031^{* * * *} \\
(0.289)\end{array}$ & & $\begin{array}{c}0.989^{* * * *} \\
(0.291)\end{array}$ & & $\begin{array}{l}0.943^{* * * *} \\
(0.292)\end{array}$ \\
\hline Price $_{\text {cst }} \times$ EPL_REGULAR $_{\text {ct- } 1}$ & & $\begin{array}{l}-0.0293^{* * *} \\
(0.00998)\end{array}$ & $\begin{array}{c}-0.0281^{* * *} \\
(0.00988)\end{array}$ & & \\
\hline Price $_{\text {cst }} \times$ EPL_OVERALL & & & & $\begin{array}{l}-0.0303^{* * * *} \\
(0.00946)\end{array}$ & $\begin{array}{l}-0.0280^{\text {**** }} \\
(0.00942)\end{array}$ \\
\hline Industry output_gap ${ }_{\text {cst }}$ & $\begin{array}{l}0.474^{* * *} \\
(0.0244)\end{array}$ & $\begin{array}{l}0.476^{* * *} \\
(0.0242)\end{array}$ & $\begin{array}{l}0.475^{* * *} \\
(0.0242)\end{array}$ & $\begin{array}{l}0.473^{\text {*** }} \\
(0.0244)\end{array}$ & $\begin{array}{l}0.473^{* * *} \\
(0.0243)\end{array}$ \\
\hline National output_gap & $\begin{array}{l}-0.417^{* * *} \\
(0.0905)\end{array}$ & $\begin{array}{l}-0.433^{* * * *} \\
(0.0910)\end{array}$ & $\begin{array}{l}-0.422^{* * * *} \\
(0.0905)\end{array}$ & $\begin{array}{c}-0.449^{* * * *} \\
(0.0910)\end{array}$ & $\begin{array}{l}-0.438^{* * *} \\
(0.0908)\end{array}$ \\
\hline \multicolumn{6}{|l|}{ Fixed effects } \\
\hline Country*Industry & Yes & Yes & Yes & Yes & Yes \\
\hline Industry*Time & Yes & Yes & Yes & Yes & Yes \\
\hline $\mathbf{N}$ & 4136 & 4136 & 4136 & 4136 & 4136 \\
\hline Nb Groups & 288 & 288 & 288 & 288 & 288 \\
\hline $\mathbf{R}^{2}$ within & 0.4392 & 0.4391 & 0.4415 & 0.4365 & 0.4387 \\
\hline
\end{tabular}

Robust Standard errors in parentheses, ${ }^{*} p<0.10,{ }^{* * *} p<0.05,{ }^{* * *} p<0.01$ 
Table 5

Robustness, cluster. Dependent variable: capital share (Factor cost, adjusted)

\begin{tabular}{|c|c|c|c|c|c|}
\hline & (1) & (2) & (3) & (4) & (5) \\
\hline Relative_price $_{\text {cst }}$ & $\begin{array}{l}0.122^{* * * *} \\
(0.0394)\end{array}$ & $\begin{array}{l}0.244^{* * *} \\
(0.0523)\end{array}$ & $\begin{array}{l}0.189^{* * * *} \\
(0.0613)\end{array}$ & $\begin{array}{l}0.240^{* * * *} \\
(0.0510)\end{array}$ & $\begin{array}{c}0.186^{* * *} \\
(0.0626)\end{array}$ \\
\hline Indirect_price $_{\text {cst-1 }}$ & $\begin{array}{c}-0.358^{* *} \\
(0.148)\end{array}$ & $\begin{array}{l}-0.383^{* *} \\
(0.149)\end{array}$ & $\begin{array}{c}-0.366^{* *} \\
(0.147)\end{array}$ & $\begin{array}{l}-0.370^{* *} \\
(0.148)\end{array}$ & $\begin{array}{c}-0.354^{* * *} \\
(0.147)\end{array}$ \\
\hline UNRS_M2554 $4_{\text {ct-1 }}$ & $\begin{array}{l}0.559^{* * *} \\
(0.123)\end{array}$ & $\begin{array}{c}0.591^{* * * *} \\
(0.119)\end{array}$ & $\begin{array}{c}0.562^{* * * *} \\
(0.123)\end{array}$ & $\begin{array}{c}0.591^{* * * *} \\
(0.122)\end{array}$ & $\begin{array}{c}0.565^{* * *} \\
(0.127)\end{array}$ \\
\hline EPL_REGULAR $_{\mathrm{ct}-1}$ & $\begin{array}{c}-0.0292^{* *} \\
(0.0134)\end{array}$ & $\begin{array}{c}-0.0274^{* *} \\
(0.0135)\end{array}$ & $\begin{array}{c}-0.0275^{* *} \\
(0.0135)\end{array}$ & & \\
\hline EPL_OVERALL $_{\text {ct-1 }}$ & & & & $\begin{array}{l}-0.00584 \\
(0.00850)\end{array}$ & $\begin{array}{l}-0.00590 \\
(0.00848)\end{array}$ \\
\hline Price $_{\text {cst }} \times$ UNRS_M255 & $\begin{array}{l}1.031^{* *} \\
(0.520)\end{array}$ & & $\begin{array}{l}0.989^{*} \\
(0.525)\end{array}$ & & $\begin{array}{l}0.943^{*} \\
(0.525)\end{array}$ \\
\hline Price $_{\text {cst }} \times$ EPL_REGULAR $_{\text {ct } 1}$ & & $\begin{array}{l}-0.0293 \\
(0.0226)\end{array}$ & $\begin{array}{l}-0.0281 \\
(0.0223)\end{array}$ & & \\
\hline Price $_{\text {cst }} \times$ EPL_OVERALL & & & & $\begin{array}{l}-0.0303 \\
(0.0214)\end{array}$ & $\begin{array}{l}-0.0280 \\
(0.0213)\end{array}$ \\
\hline Industry output_gap cst & $\begin{array}{l}0.474^{* * *} \\
(0.0268)\end{array}$ & $\begin{array}{l}0.476^{* * *} \\
(0.0266)\end{array}$ & $\begin{array}{l}0.475^{* * * *} \\
(0.0267)\end{array}$ & $\begin{array}{l}0.473^{* * *} \\
(0.0266)\end{array}$ & $\begin{array}{l}0.473^{* * *} \\
(0.0267)\end{array}$ \\
\hline National output_gap ${ }_{c t}$ & $\begin{array}{c}-0.417^{* * *} \\
(0.0951)\end{array}$ & $\begin{array}{c}-0.433^{* * *} \\
(0.0984)\end{array}$ & $\begin{array}{c}-0.422^{* * *} \\
(0.0945)\end{array}$ & $\begin{array}{c}-0.449^{* * * *} \\
(0.0945)\end{array}$ & $\begin{array}{l}-0.438^{* * * *} \\
(0.0912)\end{array}$ \\
\hline \multicolumn{6}{|l|}{ Fixed effects } \\
\hline Country $\times$ Industry & Yes & Yes & Yes & Yes & Yes \\
\hline Industry $\times$ Time & Yes & Yes & Yes & Yes & Yes \\
\hline Country $\times$ Time & No & No & No & No & No \\
\hline $\mathbf{N}$ & 4136 & 4136 & 4136 & 4136 & 4136 \\
\hline Nb Groups & 288 & 288 & 288 & 288 & 288 \\
\hline $\mathbf{R}^{2}$ within & 0.4392 & 0.4391 & 0.4415 & 0.4365 & 0.4387 \\
\hline
\end{tabular}

Robust Standard errors in parentheses, ${ }^{*} p<0.10,{ }^{* *} p<0.05,{ }^{* * *} p<0.01$ 
Table 6

Robustness, alternative measures of capital share.

\begin{tabular}{|c|c|c|c|c|c|}
\hline & $\begin{array}{c}\text { Adjusted } \\
\text { Factor Cost }\end{array}$ & Unadjusted & $\begin{array}{l}\text { Unadjusted } \\
\text { Factor Cost }\end{array}$ & Unadjusted & $\begin{array}{l}\text { Unadjusted } \\
\text { Factor Cost }\end{array}$ \\
\hline Relative_price $_{\text {cst }}$ & $\begin{array}{l}0.189^{* * *} \\
(0.0289)\end{array}$ & $\begin{array}{l}0.150^{* * *} \\
(0.0272)\end{array}$ & $\begin{array}{l}0.140^{* * *} \\
(0.0271)\end{array}$ & $\begin{array}{l}0.168^{* * *} \\
(0.0269)\end{array}$ & $\begin{array}{l}0.157^{* * * *} \\
(0.0268)\end{array}$ \\
\hline Indirect_price $_{\text {cst-1 }}$ & $\begin{array}{c}-0.366^{* * *} \\
(0.0732)\end{array}$ & $\begin{array}{c}-0.323^{* * *} \\
(0.0699)\end{array}$ & $\begin{array}{c}-0.338^{* * *} \\
(0.0675)\end{array}$ & $\begin{array}{c}-0.325^{* * *} \\
(0.0688)\end{array}$ & $\begin{array}{c}-0.340^{* * *} \\
(0.0664)\end{array}$ \\
\hline UNRS_M2554 ct-1 & $\begin{array}{l}0.562^{* * * *} \\
(0.0608)\end{array}$ & $\begin{array}{l}0.640^{* * * *} \\
(0.0557)\end{array}$ & $\begin{array}{l}0.605^{* * *} \\
(0.0558)\end{array}$ & $\begin{array}{l}0.594^{* * * *} \\
(0.0559)\end{array}$ & $\begin{array}{l}0.559^{* * * *} \\
(0.0560)\end{array}$ \\
\hline EPL_REGULAR $_{\text {ct-1 }}$ & $\begin{array}{l}-0.0275^{* * *} \\
(0.00628)\end{array}$ & $\begin{array}{l}-0.0373^{* * *} \\
(0.00571)\end{array}$ & $\begin{array}{l}-0.0427^{* * * *} \\
(0.00577)\end{array}$ & $\begin{array}{l}-0.0290^{* * * *} \\
(0.00574)\end{array}$ & $\begin{array}{l}-0.0344^{* * *} \\
(0.00579)\end{array}$ \\
\hline Price $_{\text {cst }} \times$ UNRS_M2554 & $\begin{array}{l}0.989^{* * * *} \\
(0.291)\end{array}$ & $\begin{array}{l}0.446^{\circ} \\
(0.273)\end{array}$ & $\begin{array}{l}0.606^{* *} \\
(0.274)\end{array}$ & $\begin{array}{l}0.544^{* *} \\
(0.272)\end{array}$ & $\begin{array}{l}0.705^{* * *} \\
(0.274)\end{array}$ \\
\hline Price $_{\text {cst }} \times$ EPL_REGULAR ct-1 $_{-1}$ & $\begin{array}{l}-0.0281^{* * *} \\
(0.00988)\end{array}$ & $\begin{array}{l}-0.00166 \\
(0.00912)\end{array}$ & $\begin{array}{c}-0.00427 \\
(0.00911)\end{array}$ & $\begin{array}{c}-0.0109 \\
(0.00904)\end{array}$ & $\begin{array}{l}-0.0136^{\circ} \\
(0.00904)\end{array}$ \\
\hline Industry output_gap ${ }_{\text {cst }}$ & $\begin{array}{l}0.475^{* * *} \\
(0.0242)\end{array}$ & $\begin{array}{l}0.426^{* * *} \\
(0.0218)\end{array}$ & $\begin{array}{l}0.423^{* * *} \\
(0.0215)\end{array}$ & $\begin{array}{l}0.434^{* * *} \\
(0.0219)\end{array}$ & $\begin{array}{l}0.431^{* * * *} \\
(0.0217)\end{array}$ \\
\hline National output_gap & $\begin{array}{l}-0.422^{* * *} \\
(0.0905)\end{array}$ & $\begin{array}{l}-0.332^{* * * *} \\
(0.0834)\end{array}$ & $\begin{array}{c}-0.357^{* * *} \\
(0.0837)\end{array}$ & $\begin{array}{l}-0.348^{* * * *} \\
(0.0818)\end{array}$ & $\begin{array}{c}-0.373^{* * *} \\
(0.0823)\end{array}$ \\
\hline Share_of_employees ${ }_{\text {cst }}$ & & & & $\begin{array}{c}-0.394^{* * * *} \\
(0.0535)\end{array}$ & $\begin{array}{c}-0.397^{* * *} \\
(0.0534)\end{array}$ \\
\hline \multicolumn{6}{|l|}{ Fixed effects } \\
\hline Country $\times$ Industry & Yes & Yes & Yes & Yes & Yes \\
\hline Industry $\times$ Time & Yes & Yes & Yes & Yes & Yes \\
\hline Country $\times$ Time & No & No & No & No & No \\
\hline $\mathbf{N}$ & 4136 & 4136 & 4136 & 4136 & 4136 \\
\hline Nb Groups & 288 & 288 & 288 & 288 & 288 \\
\hline $\mathbf{R}^{2}$ within & 0.4415 & 0.4671 & 0.4476 & 0.4784 & 0.4595 \\
\hline
\end{tabular}

Robust Standard errors in parentheses, ${ }^{*} p<0.10,{ }^{* * *} p<0.05,{ }^{* * *} p<0.01$ 
Table 7

Robustness, countries. Dependent variable: capital share (Factor cost, adjusted)

\begin{tabular}{|c|c|c|c|c|c|c|}
\hline & Ref & $\begin{array}{l}\text { Very high } \\
\text { income }\end{array}$ & $\begin{array}{l}\text { High } \\
\text { income }\end{array}$ & $\begin{array}{l}\text { Fixed } \\
\text { effects }\end{array}$ & $\begin{array}{c}\text { Year> } \\
1997\end{array}$ & $\begin{array}{c}\text { all } \\
\text { industries } \\
\text { available }\end{array}$ \\
\hline Relative_price $_{\text {cst }}$ & $\begin{array}{l}0.189^{* * * *} \\
(0.0289)\end{array}$ & $\begin{array}{l}0.201^{* * *} \\
(0.0405)\end{array}$ & $\begin{array}{l}0.311^{* * * *} \\
(0.0768)\end{array}$ & $\begin{array}{l}0.178^{* * *} \\
(0.0289)\end{array}$ & $\begin{array}{l}0.237^{* * *} \\
(0.0408)\end{array}$ & $\begin{array}{l}0.120^{* * * *} \\
(0.0290)\end{array}$ \\
\hline Indirect_price $_{\text {cst-1 }}$ & $\begin{array}{c}-0.366^{* * * *} \\
(0.0732)\end{array}$ & $\begin{array}{c}-0.551^{\text {**** }} \\
(0.0914)\end{array}$ & $\begin{array}{l}-0.127 \\
(0.140)\end{array}$ & $\begin{array}{l}-0.182^{*} \\
(0.108)\end{array}$ & $\begin{array}{l}-0.499^{* * * *} \\
(0.0932)\end{array}$ & $\begin{array}{l}-0.404^{* * * *} \\
(0.0760)\end{array}$ \\
\hline UNRS_M2554 ct-1 $_{1}$ & $\begin{array}{l}0.562^{* * * *} \\
(0.0608)\end{array}$ & $\begin{array}{l}1.090^{* * *} \\
(0.150)\end{array}$ & $\begin{array}{c}0.116 \\
(0.0997)\end{array}$ & & $\begin{array}{l}0.876^{* * *} \\
(0.0967)\end{array}$ & $\begin{array}{l}0.465^{* * * *} \\
(0.0633)\end{array}$ \\
\hline EPL_REGULAR $R_{\text {ct-1 }}$ & $\begin{array}{l}-0.0275^{* * *} \\
(0.00628)\end{array}$ & $\begin{array}{l}-0.0440^{* * * *} \\
(0.00823)\end{array}$ & $\begin{array}{l}0.0349^{* * *} \\
(0.0158)\end{array}$ & & $\begin{array}{l}-0.0268^{* * *} \\
(0.00650)\end{array}$ & $\begin{array}{l}-0.0225^{* * * *} \\
(0.00643)\end{array}$ \\
\hline Price $_{\text {cst }} \times$ UNRS_M2554 ct-1 & $\begin{array}{l}0.989^{* * * *} \\
(0.291)\end{array}$ & $\begin{array}{l}0.0312 \\
(0.598)\end{array}$ & $\begin{array}{l}1.806^{* * *} \\
(0.492)\end{array}$ & $\begin{array}{l}0.884^{* * *} \\
(0.320)\end{array}$ & $\begin{array}{l}1.604^{* * * *} \\
(0.537)\end{array}$ & $\begin{array}{l}1.326^{* * *} \\
(0.309)\end{array}$ \\
\hline Price $_{\text {cst }} \times$ EPL_REGULAR ct-1 $_{\text {ch }}$ & $\begin{array}{l}-0.0281^{* * *} \\
(0.00988)\end{array}$ & $\begin{array}{c}-0.0415^{* * * *} \\
(0.0109)\end{array}$ & $\begin{array}{c}-0.0850^{* * * * *} \\
(0.0285)\end{array}$ & $\begin{array}{l}-0.0156^{\circ} \\
(0.0101)\end{array}$ & $\begin{array}{c}-0.0582^{* * * *} \\
(0.0148)\end{array}$ & $\begin{array}{l}-0.0113 \\
(0.0100)\end{array}$ \\
\hline Industry output_gap ${ }_{\text {cst }}$ & $\begin{array}{l}0.475^{* * *} \\
(0.0242)\end{array}$ & $\begin{array}{l}0.443^{* * *} \\
(0.0343)\end{array}$ & $\begin{array}{l}0.494^{* * *} \\
(0.0343)\end{array}$ & $\begin{array}{l}0.461^{* * *} \\
(0.0230)\end{array}$ & $\begin{array}{l}0.477^{* * *} \\
(0.0271)\end{array}$ & $\begin{array}{l}0.469^{* * * *} \\
(0.0248)\end{array}$ \\
\hline National output_gap & $\begin{array}{l}-0.422^{* * *} \\
(0.0905)\end{array}$ & $\begin{array}{c}-0.478^{* * * *} \\
(0.183)\end{array}$ & $\begin{array}{c}-0.474^{* * * *} \\
(0.124)\end{array}$ & & $\begin{array}{c}-0.512^{* * * *} \\
(0.108)\end{array}$ & $\begin{array}{c}-0.430^{* * * *} \\
(0.0958)\end{array}$ \\
\hline \multicolumn{7}{|l|}{ Fixed effects } \\
\hline Country $\times$ Industry & Yes & Yes & Yes & Yes & Yes & Yes \\
\hline Industry×Time & Yes & Yes & Yes & Yes & Yes & Yes \\
\hline Country $\times$ Time & No & No & No & Yes & No & No \\
\hline $\mathbf{N}$ & 4136 & 2025 & 2111 & 4136 & 2908 & 3724 \\
\hline Nb Groups & 288 & 123 & 165 & 288 & 288 & 252 \\
\hline $\mathbf{R}^{2}$ within & 0.4415 & 0.5049 & 0.5559 & 0.5373 & 0.4141 & 0.4553 \\
\hline
\end{tabular}

Robust Standard errors in parentheses, ${ }^{*} p<0.10,{ }^{* *} p<0.05,{ }^{* * *} p<0.01$ 
Table 8

Robustness, industries. Dependent variable: capital share (Factor cost, adjusted)

\begin{tabular}{|c|c|c|c|c|c|c|}
\hline & Ref & $\begin{array}{c}\text { Manufact } \\
\text { uring }\end{array}$ & $\begin{array}{c}\text { Non- } \\
\text { manufact } \\
\text { uring }\end{array}$ & $\begin{array}{c}\text { Without } \\
\text { 30t33 }\end{array}$ & US I/O & $\begin{array}{c}\text { US I/O } \\
\text { without } \\
\text { US }\end{array}$ \\
\hline Relative_price $_{\text {cst }}$ & $\begin{array}{c}0.189^{* * *} \\
(0.0289)\end{array}$ & $\begin{array}{l}0.207^{* * *} \\
(0.0478)\end{array}$ & $\begin{array}{l}0.168^{* * * *} \\
(0.0346)\end{array}$ & $\begin{array}{l}0.152^{* * * *} \\
(0.0186)\end{array}$ & $\begin{array}{c}0.189^{* * *} \\
(0.0287)\end{array}$ & $\begin{array}{l}0.309^{* * *} \\
(0.0388)\end{array}$ \\
\hline Indirect_price $_{\text {cst-1 }}$ & $\begin{array}{c}-0.366^{* * * *} \\
(0.0732)\end{array}$ & $\begin{array}{l}-0.197^{* *} \\
(0.0932)\end{array}$ & $\begin{array}{c}-0.609^{* * *} \\
(0.117)\end{array}$ & $\begin{array}{c}-0.238^{* * *} \\
(0.0727)\end{array}$ & & \\
\hline Indirect_price $_{\text {cst-1 }}$ (us I/O) & & & & & $\begin{array}{l}-0.404^{* * *} \\
(0.0849)\end{array}$ & $\begin{array}{l}-0.434^{* * *} \\
(0.0876)\end{array}$ \\
\hline UNRS_M2554 $4_{\text {ct-1 }}$ & $\begin{array}{l}0.562^{* * *} \\
(0.0608)\end{array}$ & $\begin{array}{l}0.697^{* * * *} \\
(0.0833)\end{array}$ & $\begin{array}{l}0.337^{* * * *} \\
(0.0879)\end{array}$ & $\begin{array}{l}0.570^{* * *} \\
(0.0618)\end{array}$ & $\begin{array}{l}0.571^{* * * *} \\
(0.0605)\end{array}$ & $\begin{array}{l}0.585^{* * *} \\
(0.0601)\end{array}$ \\
\hline $\mathbf{E P L}_{-} \mathbf{R E G U L A R _ { \mathrm { ct } - 1 }}$ & $\begin{array}{l}-0.0275^{* * *} \\
(0.00628)\end{array}$ & $\begin{array}{l}-0.0202^{* *} \\
(0.00853)\end{array}$ & $\begin{array}{c}-0.0334^{* * *} \\
(0.00896)\end{array}$ & $\begin{array}{c}-0.0329^{* * * *} \\
(0.00640)\end{array}$ & $\begin{array}{l}-0.0316^{* * *} \\
(0.00636)\end{array}$ & $\begin{array}{l}-0.0287^{* * * *} \\
(0.00628)\end{array}$ \\
\hline Price $_{\text {cst }} \times$ UNRS_M2554 ct-1 $_{1}$ & $\begin{array}{l}0.989^{* * * *} \\
(0.291)\end{array}$ & $\begin{array}{l}1.618^{* * * *} \\
(0.466)\end{array}$ & $\begin{array}{c}0.441 \\
(0.384)\end{array}$ & $\begin{array}{c}0.329 \\
(0.302)\end{array}$ & $\begin{array}{l}0.968^{* * *} \\
(0.292)\end{array}$ & $\begin{array}{c}0.868^{* * *} \\
(0.289)\end{array}$ \\
\hline Price $_{\text {cst }} \times$ EPL_REGULAR ct-1 $_{-1}$ & $\begin{array}{l}-0.0281^{* * *} \\
(0.00988)\end{array}$ & $\begin{array}{c}-0.0447^{* * * *} \\
(0.0146)\end{array}$ & $\begin{array}{c}-0.0163 \\
(0.0128)\end{array}$ & $\begin{array}{l}-0.0189^{* * * *} \\
(0.00624)\end{array}$ & $\begin{array}{l}-0.0278^{* * * *} \\
(0.00982)\end{array}$ & $\begin{array}{c}-0.0689^{* * * *} \\
(0.0145)\end{array}$ \\
\hline Industry output_gap & $\begin{array}{l}0.475^{* * *} \\
(0.0242)\end{array}$ & $\begin{array}{l}0.499^{* * * *} \\
(0.0274)\end{array}$ & $\begin{array}{l}0.423^{* * *} \\
(0.0476)\end{array}$ & $\begin{array}{l}0.457^{* * * *} \\
(0.0245)\end{array}$ & $\begin{array}{l}0.475^{* * *} \\
(0.0242)\end{array}$ & $\begin{array}{l}0.486^{* * *} \\
(0.0249)\end{array}$ \\
\hline National output_gap ${ }_{c t}$ & $\begin{array}{l}-0.422^{* * * *} \\
(0.0905)\end{array}$ & $\begin{array}{c}-0.464^{* * *} \\
(0.124)\end{array}$ & $\begin{array}{c}-0.348^{* * *} \\
(0.129)\end{array}$ & $\begin{array}{l}-0.344^{* * * *} \\
(0.0933)\end{array}$ & $\begin{array}{l}-0.396^{* * * *} \\
(0.0907)\end{array}$ & $\begin{array}{c}-0.416^{* * *} \\
(0.0923)\end{array}$ \\
\hline \multicolumn{7}{|l|}{ Fixed effects } \\
\hline Country $\times$ Industry & Yes & Yes & Yes & Yes & Yes & Yes \\
\hline Industry $\times$ Time & Yes & Yes & Yes & Yes & Yes & Yes \\
\hline Country $\times$ Time & No & No & No & No & No & No \\
\hline $\mathbf{N}$ & 4136 & 2342 & 1794 & 4358 & 4136 & 3776 \\
\hline Nb Groups & 288 & 164 & 124 & 288 & 288 & 304 \\
\hline $\mathbf{R}^{2}$ within & 0.4415 & 0.4521 & 0.4442 & 0.4250 & 0.4406 & 0.4762 \\
\hline
\end{tabular}

Robust Standard errors in parentheses, ${ }^{*} p<0.10,{ }^{* * *} p<0.05,{ }^{* * *} p<0.01$ 
Graph 1

Marginal effect of relative price on the capital share with respect to the unemployment rate. ${ }^{19}$

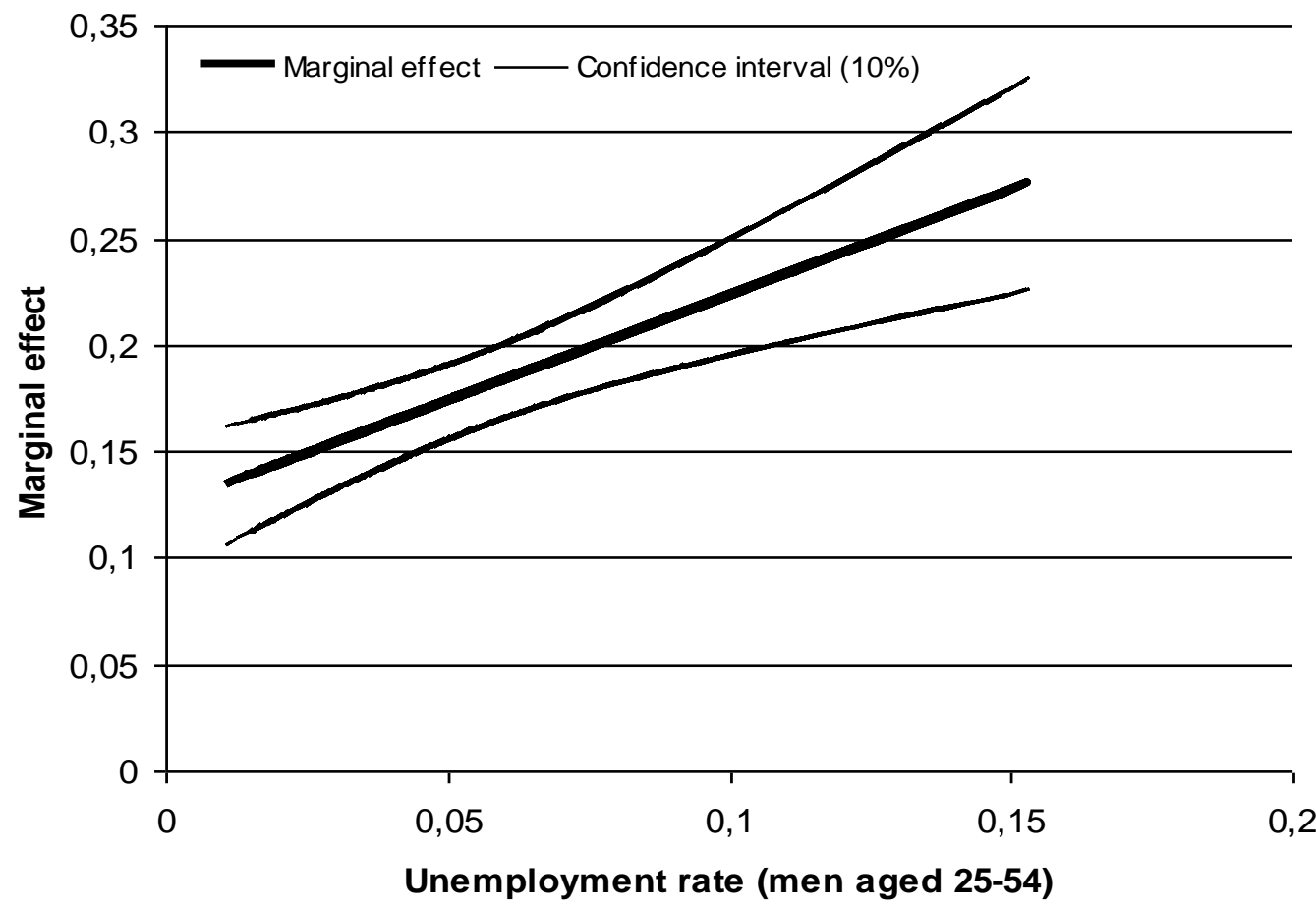

Graph 2

Marginal effect of the relative price on the capital share with respect to the employment protection legislation index ${ }^{20}$

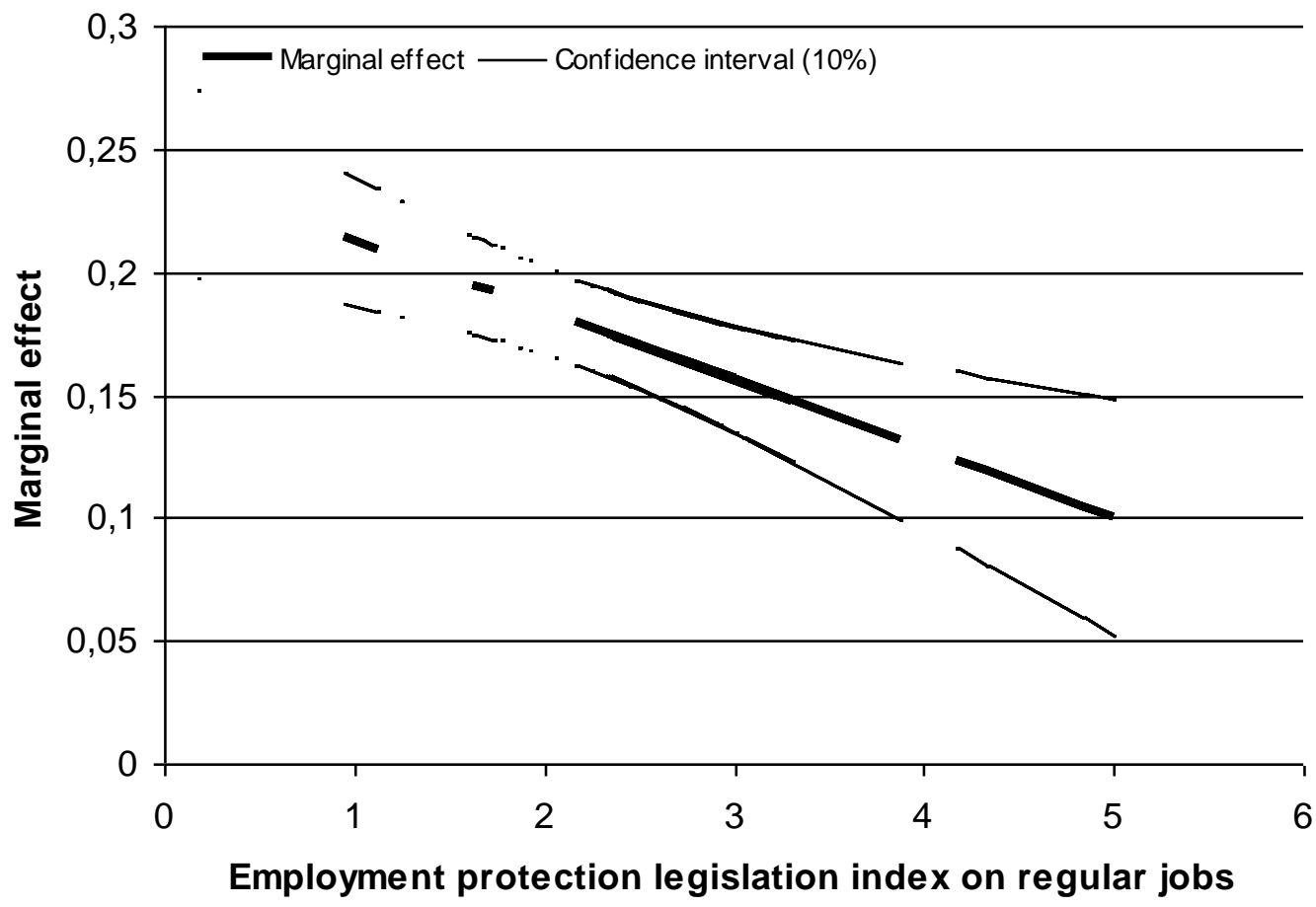

19 The marginal effect of price conditional on the unemployment rate is computed setting the EPL to its median value (2.31). We use the coefficient from table 4 column 3 to compute marginal effects.

20 The marginal effect of prices conditional on the EPL index on regular jobs is computed setting the unemployment rate to its median value (0.052). We use coefficient from table 4 column 3 to compute marginal effects. 